\title{
A State-of-the-Art Review of Nanoparticles Application in Petroleum with a Focus on Enhanced Oil Recovery
}

\author{
Madhan Nur Agista ${ }^{1,2}$, Kun Guo ${ }^{1,3, * \text { (D) and Zhixin Yu }}{ }^{1, *(D)}$ \\ 1 Department of Energy and Petroleum Engineering, University of Stavanger, 4036 Stavanger, Norway; \\ madhan@aurorisgroup.com \\ 2 Auroris Energy, Jakarta 12950, Indonesia \\ 3 The National IOR Centre of Norway, University of Stavanger, 4036 Stavanger, Norway \\ * Correspondence: kun.guo@uis.no (K.G.); zhixin.yu@uis.no (Z.Y.); \\ Tel.: +47-5183-2198 (K.G.); +47-5183-2238 (Z.Y.)
}

Received: 21 April 2018; Accepted: 15 May 2018; Published: 25 May 2018

\begin{abstract}
Research on nanotechnology application in the oil and gas industry has been growing rapidly in the past decade, as evidenced by the number of scientific articles published in the field. With oil and gas reserves harder to find, access, and produce, the pursuit of more game-changing technologies that can address the challenges of the industry has stimulated this growth. Nanotechnology has the potential to revolutionize the petroleum industry both upstream and downstream, including exploration, drilling, production, and enhanced oil recovery (EOR), as well as refinery processes. It provides a wide range of alternatives for technologies and materials to be utilized in the petroleum industry. Nanoscale materials in various forms such as solid composites, complex fluids, and functional nanoparticle-fluid combinations are key to the new technological advances. This paper aims to provide a state-of-the-art review on the application of nanoparticles and technology in the petroleum industry, and focuses on enhanced oil recovery. We briefly summarize nanotechnology application in exploration and reservoir characterization, drilling and completion, production and stimulation, and refinery. Thereafter, this paper focuses on the application of nanoparticles in EOR. The different types of nanomaterials, e.g., silica, aluminum oxides, iron oxide, nickel oxide, titanium oxide, zinc oxide, zirconium oxide, polymers, and carbon nanotubes that have been studied in EOR are discussed with respect to their properties, their performance, advantages, and disadvantages. We then elaborate upon the parameters that will affect the performance of nanoparticles in EOR, and guidelines for promising recovery factors are emphasized. The mechanisms of the nanoparticles in the EOR processes are then underlined, such as wettability alteration, interfacial tension reduction, disjoining pressure, and viscosity control. The objective of this review is to present a wide range of knowledge and expertise related to the nanotechnology application in the petroleum industry in general, and the EOR process in particular. The challenges and future research directions for nano-EOR are pinpointed.
\end{abstract}

Keywords: nanotechnology; nanoparticle; petroleum; enhanced oil recovery; recovery mechanism; wettability alteration; interfacial tension reduction

\section{Introduction}

Hydrocarbon is a major energy source for human civilization, and it is predicted to remain the primary source of energy in the coming decades. However, most oil fields have already reached or will soon reach the declining stage of production, even though a large fraction of the original oil in 
place (OOIP) has not yet been recovered. Based on the U.S. Department of Energy (DoE, Washington, DC, USA) data, $67 \%$ of the total oil in the U.S. will remain in the reservoirs because of the limitations of the technology used to extract residual hydrocarbon [1]. As cheap and reliable renewable energy sources are not yet available, fundamental studies on enhanced oil recovery (EOR) are critical to develop technologies enabling a high recovery factor from oil reservoirs. Various EOR technologies have been applied and proven to significantly increase hydrocarbon recovery. These include thermal, miscible, and chemical methods, as well as some new technologies (microbial, low salinity flooding). More recently, nanoparticles and nanotechnology have been proposed as a promising EOR method since nanoparticles can penetrate the pore throat and change the reservoir properties considerably to increase oil recovery [1-6].

Over the past years, numerous studies have shown promising results of nanomaterials application for improving hydrocarbon recovery. Laboratory studies have shown that surface-coated silica nanoparticles can stabilize emulsions and improve mobility control in the EOR process $[7,8]$. Nanoparticles (NPs) have also been reported to alter rock wettability and reduce interfacial tension when used as EOR agents $[3,9,10]$. Different parameters of nanoparticles such as size, concentration, ionic composition, and type have been studied in relation to their effect on EOR [11,12].

This paper presents a comprehensive review of the recent applications of nanoparticles and nanotechnology in the petroleum industry in general and EOR in particular, and aims to provide insights for researchers to work in the nano-EOR field. Some earlier reviews on nanomaterials on EOR have been published elsewhere, which are mainly from either a mechanistic or an experimental perspective [13-15]. This review is based on a material approach for nano-EOR and will focus on the effect of NP type and parameters on EOR. Furthermore, the nanoparticle application in different fields such as exploration, drilling, production, and refining is briefly summarized at the start of the review. Experimental studies that have been done with different types of nanoparticles are discussed along with their proposed mechanisms and driving parameters.

\section{Applications of Nanotechnology in the Petroleum Industry}

Nanotechnology has the potential to revolutionize the petroleum industry both upstream and downstream, including exploration, drilling, production, and EOR, as well as refinery processes [1,16-18]. It provides a wide range of alternatives for technologies and materials to be utilized in the petroleum industry. Nanoscale materials in various forms such as solid composites, complex fluids, and functional NP-fluid combinations are key to the new technological advances [19]. The number of studies on nanotechnology related to the petroleum industry has been growing rapidly in the past few years. Figure 1 presents the number of scientific articles published in this field, displaying a large number of research activities, even during the down time of the petroleum industry. Specifically, engineered nanoparticles have been of particular interest for their potential applications. A summary of important studies related to the utilization of nanoparticles in different fields is presented in Table 1 and will be illustrated in the following sections.

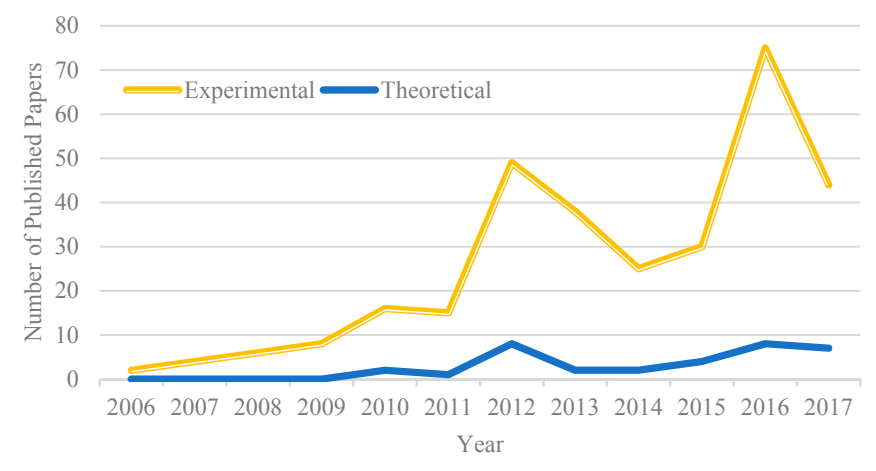

Figure 1. Research on nanotechnology application in the petroleum industry. 
Table 1. Summary of the literature studies.

\begin{tabular}{|c|c|c|c|}
\hline Area & Nano Type & Purpose & References \\
\hline \multirow{6}{*}{ Exploration } & $\begin{array}{l}\text { Hyperpolarized silicon } \\
\text { NPs }\end{array}$ & $\begin{array}{l}\text { Imaging sensors for oil in a } \\
\text { hydrocarbon reservoir }\end{array}$ & [20] \\
\hline & Nano-optical fiber & $\begin{array}{l}\text { Detect oil-microbe, estimate reservoir } \\
\text { pressure and temperature }\end{array}$ & [21] \\
\hline & Nano-robots & $\begin{array}{l}\text { Well logging and borehole } \\
\text { measurement (patent) }\end{array}$ & [22] \\
\hline & $\begin{array}{l}\text { Coated carbon-nano } \\
\text { structure }\end{array}$ & $\begin{array}{l}\text { Real-time oil reservoir evaluation with } \\
\text { two-dimensional detection technology }\end{array}$ & [23] \\
\hline & Magnetic NP & $\begin{array}{l}\text { Detect flood front, fluid contact, } \\
\text { hydrocarbon bypass and fracture }\end{array}$ & [24] \\
\hline & Superparamagnetic NP & $\begin{array}{l}\text { Cross well magnetic sensor for tracking } \\
\text { flood front }\end{array}$ & [25] \\
\hline \multirow{7}{*}{$\begin{array}{l}\text { Drilling \& } \\
\text { Completion }\end{array}$} & Silica NPs & $\begin{array}{l}\text { Reduce or stop water invasion in shale } \\
\text { by plugging shale pore }\end{array}$ & {$[26,27]$} \\
\hline & Nanodiamond & $\begin{array}{l}\text { Improve drilling process in harsh and } \\
\text { demanding environment }\end{array}$ & {$[28]$} \\
\hline & Silica and alumina NPs & Cement accelerator & [29] \\
\hline & $\mathrm{MgO}$ and $\mathrm{ZnO} \mathrm{NPs}$ & $\begin{array}{l}\text { Improve thermal stability of drilling } \\
\text { fluid }\end{array}$ & [30] \\
\hline & Nanoclay & $\begin{array}{l}\text { Reduce permeability and porosity of } \\
\text { cement and enhanced compressive } \\
\text { strength }\end{array}$ & {$[31]$} \\
\hline & Carbon nanotubes & Improve compressive strength in HPHT & [32] \\
\hline & $\begin{array}{l}\text { Cellulose nanofibers \& } \\
\text { graphene nano-platelets }\end{array}$ & $\begin{array}{l}\text { Increase yield stresses, degree of } \\
\text { hydration, flexural and compressive } \\
\text { strengths }\end{array}$ & {$[33]$} \\
\hline \multirow{5}{*}{$\begin{array}{l}\text { Stimulation \& } \\
\text { Production }\end{array}$} & Pyroelectric NP & $\begin{array}{l}\text { Additive for fracturing + viscoelastic } \\
\text { surfactant to increase efficiency in } \\
\text { fracturing }\end{array}$ & {$[34]$} \\
\hline & Ni-Fe NPs & Hydrate mitigation in the well & [35] \\
\hline & $\mathrm{ZnO}$ NPs & $\begin{array}{l}\text { Increase low shear rate viscosity on } \\
\text { Threadlike micelle fluids and more } \\
\text { stable }\end{array}$ & {$[36]$} \\
\hline & Metal oxides based & $\begin{array}{l}\text { Improve fracturing fluid stability and } \\
\text { viscosity at high temperature ( } 300 \mathrm{~F}) \text {. }\end{array}$ & {$[37]$} \\
\hline & Non-ferrous NPS & $\begin{array}{l}\text { Combine with surfactant for IFT } \\
\text { reduction }\end{array}$ & [38] \\
\hline \multirow{6}{*}{ Refinery } & Nano-supported HDS & Patent on nano-supported HDS catalyst & [39] \\
\hline & $\mathrm{MoS}_{2}$ nano-catalyst & $\begin{array}{l}\text { Observe atomic-scale edge structures of } \\
\mathrm{MoS}_{2}\end{array}$ & [40] \\
\hline & $\mathrm{TiO}_{2}$ NPs & $\begin{array}{l}\text { Improve water treatment by reducing } \\
\text { fouling effect }\end{array}$ & [41] \\
\hline & $\begin{array}{c}\mathrm{TiO}_{2}, \mathrm{ZrO}_{2} \text {, and } \mathrm{SiO}_{2} \\
\text { NPs }\end{array}$ & $\begin{array}{l}\text { Additive for stabilizing asphaltene in } \\
\text { oil under acidic conditions }\end{array}$ & {$[42]$} \\
\hline & Magnetic NPs & $\begin{array}{l}\text { Accelerate oil removal in water-oil } \\
\text { emulsion }\end{array}$ & [43] \\
\hline & $\begin{array}{l}\text { Nickel oxides and } \mathrm{Al}_{2} \mathrm{O}_{3} \\
\text { NPs }\end{array}$ & $\begin{array}{l}\text { Patent on nanocatalyst for } \\
\text { hydrocracking }\end{array}$ & [44] \\
\hline
\end{tabular}




\subsection{Exploration and Reservoir Characterization}

Recently, hydrocarbon exploration has begun to be carried out in more challenging areas involving high risk and investment. It is therefore necessary to develop methods that are technically and economically feasible for exploration. "Nano-sensors" have been proposed for seismic characterization, interpretation, and formation evaluation in geochemical exploration [45]. When NPs are injected into the reservoir, some will pass through pores while others will be adsorbed onto the grain surface. Information on the chemical and physical properties of the rock and 3D distribution of the formation can be obtained from analysis of the adsorbed NPs [46]. Moreover, core and surface characteristics of NPs can be engineered that will induce significant changes in optical, magnetic, and electrical properties, making them ideal candidates for sensors or imaging agents [47].

Numerous researchers have investigated the novel application of NPs as nano-sensors. In 2007, Song et al. [20] introduced the idea of using hyperpolarized silicon NPs as nanosensors in oil and gas exploration. Hyperpolarized NPs were first tested with promising results in bio-medical engineering as alternative tracker particles for magnetic resonance imaging (MRI) [48,49]. Jahagirdar [21] proposed the detection of oil-microbes in the reservoir using nano-optical fibers based on the principle of Resonance Raman Spectroscopy (RRS). As microbes only survive in specific conditions, this method can be used to indirectly measure reservoir properties such as pressure, temperature, and salinity. $\mathrm{Li}$ et al. [23] were granted a patent for real-time two dimensional analysis for oil reservoir evaluation, using an engineered carbon nanostructure and surface sensors. Magnetic NPs for detecting flood front and oil-water interfaces have been studied, and the result showed the capability of travel-time tomography to detect magnetic NPs in different media, which was a big step in the utilization of magnetic nanosensors [24]. Similarly, Rahmani et al. [25] successfully employed superparamagnetic NP for tracking floodfront using a crosswell magnetic sensing method. The most recent advance in the use of nanotechnology in oil and gas exploration is the utilization of reservoir nano-robots by Liu et al. [50], who successfully tested a nano detection device which integrates a reservoir sensor, a micro-dynamic system, and micro-signal transmission. A patent was granted to Pratyush and Sumit [22] for a nano-robot system for well logging and measurement.

These studies show that NPs have the potential to be utilized for reservoir characterization and hydrocarbon exploration. However, the problem that needs to be solved to make nanosensors feasible lies in protecting the sensor from degradation by fouling while at the same time getting the sensors to reach reservoir fluids.

\subsection{Drilling and Completion}

Nanotechnology for drilling and completion has been widely studied for the past few years, including its application in mud additives, cementing additives, and drilling tools. Some types of NPs are proposed as the solution for several drilling operation challenges such as shallow water, unconsolidated formation, borehole instability, lost circulation, torque and drag, pipe sticking, gumbo and bit bailing, the gas hydrate zone, acid gas, high-pressure and high-temperature (HPHT), and fracturing fluids [51].

\subsubsection{Mud Additives}

Nanomaterials such as silica and graphene have been suggested as drilling fluid additives [52]. Nano-based mud contains at least one additive using nanomaterial with a size range between 1-100 $\mathrm{nm}$ [51,53]. Sharma et al. [26] observed that silica NPs reduced shale invasion by 10-100 times, leading to improved stability of the mud at elevated pressures and temperatures at different rheology values. Hoelscher et al. [54] performed experiments on Marcellus and Mancos shales with $3 \mathrm{wt} \%$ of silica NPs as additives in water-based mud and found that silica NPs could physically plug the shale and significantly reduce the fluid invasion in the shale zone at a lower loading level in the water-based mud. Similarly, Cai et al. [27] performed experimental tests with $10 \mathrm{wt} \%$ of six types of silica NPs in 
the Atoka shale and found a drastic reduction in shale permeability impairment. They also observed that the mud had a higher plastic viscosity, lower yield point, and reduced fluid loss. Srivatsa et al. [55] conducted an experimental study using a combination of biopolymer, surfactant, and nanoparticle for mud additives. They concluded that nanoparticles combined with biopolymers and surfactants could be a solution to solid free fluids in horizontal drilling.

Metallic and metal oxide-based NPs for enhancing the properties of drilling fluids have also been investigated [30,56,57], specifically iron-based and calcium-based NPs [57], and $\mathrm{MgO}$ and ZnO NPs [30]. Adding NPs was found to improve the thermal stability of drilling fluids and control the filtration loss from the reservoir. Recently, Ho et al. [58] investigated the effect of a graphene nano-sheet with a concentration range from $25 \mathrm{ppm}$ to $100 \mathrm{ppm}$ and found that graphene in oil-based fluid exhibited a higher viscosity with shear rate ranges from $0-140 \mathrm{~s}^{-1}$ and behaved like a Newtonian fluid although it is classified as a Bingham fluid.

\subsubsection{Cement Additives}

Nanoparticles also exhibit many advantages for cement additives. Many types of NPs such as nano-clay [31], silica [29,59], alumina [29], and magnesium oxide [60] have been studied as cement additives. Silica NP has proved to improve cement slurry stability, rheology, and hydration degree by acting as both an accelerator and mechanical properties enhancer $[29,59]$. The nanoparticle can also improve flexibility, reducing the permeability and compressive strength of the cement $[31,61]$. In particular, a carbon nanotube (CNT) has been shown to significantly improve cement compressive strength in HPHT conditions [32]. Sun et al. [33] combined cellulose nanofibers (CNF) and graphene nano-platelets (GNP) for oil well cement additives and concluded that the addition increased yield stresses and degree of hydration, which enhanced both the flexural and compressive strength of the cement.

\subsubsection{Drilling Tools}

Nanotechnology for drilling and completion can also be applied to drilling tools by nano-modification. The drilling process can be improved by using a nano-ceramic coating for drill bits, which can enhance the lifespan of the drilling tools [62]. Another alternative is to use nano-diamond to improve the drilling efficiency in a harsh and demanding environment [28]. There have been several patents on the nanotechnology related to drilling [63,64] and cementing [65-67], and the number will likely increase as the demand for new technology in the drilling and completion process grows. Nanotechnology will bring the future of drilling and completion technology into the "Smart Fluid" era $[1,51]$.

\subsection{Production and Stimulation}

\subsubsection{Production Problem Solution}

Various problems that occur during the production process can reduce the production efficiency. Wu et al. [68] proposed nanotechnology as an alternative solution to the liquid loading problem in deep gas wells during the production process. They proved that engineered silica NPs with a temperature resistance up to $150{ }^{\circ} \mathrm{C}$, salinity resistance of about $250 \mathrm{~g} / \mathrm{L}$, and $\mathrm{H}_{2} \mathrm{~S}$ resistance up to $0.04 \%$ could solve the liquid loading problem by creating stable gas-liquid foams. Silica NPs are also beneficial for preventing the development of wax in the pipe during oil and gas production. Recently, Sun et al. [69] discovered that modified nano-silica/EVA (ethylene vinyl acetate) could prevent the development of wax crystals and disperse them by heterogeneous nucleation. Other production problems such as hydrate formation could be solved by injecting self-heating Ni-Fe NPs into the hydrate area. Ni-Fe NPs are preferred because they have a high nucleation latency period, fast heat transfer property, and ecofriendly characteristics [35]. 
Nanoparticles are also suggested for improving water treatment, as inhibitors for asphaltene, and for improving the separation of the water-oil emulsion during hydrocarbon treatment. Sotto et al. [41] studied the effect of NP aggregation on polyether-sulfone (PES)- $\mathrm{TiO}_{2}$ that can potentially improve the treatment by reducing the fouling effect. Mohammadi et al. [42] reported that $\mathrm{TiO}_{2}, \mathrm{ZrO}_{2}$, and $\mathrm{SiO}_{2} \mathrm{NPs}$ have potential uses for stabilizing asphaltene particles via hydrogen bonding between NPs and asphaltene in acidic conditions. Similarly, Davidson et al. [70] applied the hyperthermia concept of magnetic induction heating to prevent wax deposition during production and refining. In addition, NPs can also be utilized for separating oil-water emulsion. Studies proved that magnetic NPs [43] and silica NPs [71] can remove oil droplets from the emulsion significantly faster than conventional demulsifiers.

\subsubsection{Stimulation Process Improvement}

NPs have been studied for improving hydraulic fracturing and acidizing jobs [72]. Huang et al. [73] introduced nanoparticle-coated proppant which has the ability to maintain viscosity at high temperature, control fluid loss, and reduce fines migration. NPs can pass through the pore throat and flow back easily with the producing fluid, which can preserve reservoir permeability. Crews et al. [34] reported the use of pyroelectric NPs combined with a viscoelastic surfactant (VES) to increase the fracturing efficiency and improve production rates. Barati et al. [74] applied polyelectrolyte complex NPs, which worked to clean up fracturing fluids by delaying the release of enzymes that cause premature gel breaking and improve fracturing efficiency. Crews and Gomaa [36] found that $\mathrm{ZnO}$ NPs could raise the low shear rate viscosity of threadlike micellar fluids that exhibit similar behavior as crosslinked polymer systems. Li et al. [37] conducted experimental studies on the effect of metal oxide NPs on fracturing fluids and found that adding NPs to the fracturing fluid improved the viscosity by $23-116 \%$ at an elevated temperature and reduced polymer loading.

These studies suggest that NPs have great potential for stimulation and for solving production problems. Several patents based on these studies have been granted for nanotechnology related to hydraulic fracturing, including nano-proppant for fracture conductivity by Ghahfarokhi [75] and high-temperature fracturing fluids using nano crosslinkers by Al-Muntasheri [76].

\subsection{Refining}

The downstream industry is facing challenges in reducing sulfur and $\mathrm{CO}_{2}$ emissions while also increasing production to meet the fast-growing energy demand [1]. These challenges are stimulating the industry to engage in more cost-effective, energy-efficient, and technologically-focused development [4].

The concept of nanocatalysts for handling heavy oil production was proposed in 1997 by Ying and Sun [77] and became more popular in the refining industry because they are more efficient than conventional catalysts due to the higher surface area-to-volume ratio. The approach of imaging the $\mathrm{MoS}_{2}$ nanocatalyst by Kisielowski et al. [78] led to further research on the substitution of conventional $\mathrm{MoS}_{2}$ with $\mathrm{MoS}_{2}$ NPs as a catalyst for industrial oil refining [40]. Mohajeri et al. [39] patented a nano-supported hydrodesulfurization (HDS) catalyst for treating sulfur in hydrocarbon feedstock. Recently, Patiño and Cortés [44] were granted a patent on the application of a nanocatalyst for hydrocracking that consists of nickel oxide NPs supported on alumina NPs, which are able to enhance the thermal catalytic cracking of heavy oil.

\section{Nanoparticles in EOR}

Due to the continuous growth in the global energy demand, new technology for finding hydrocarbon sources or for enhancing oil recovery needs to be developed [1]. The fact that finding new sources of hydrocarbon is difficult and that most oil fields have $60 \%$ to $70 \%$ of non-producible hydrocarbon in place drives the development of novel technologies for EOR [4]. The use of NP in EOR has several advantages such as (1) good stability, because the surface force is more dominant 
than gravity; (2) the size and shape of NPs can be facilely modified during the manufacturing process with high flexibility; (3) surface chemical properties of NPs can be easily tailored to be hydrophilic or hydrophobic; and (4) the most often applied EOR NP is silica, of which $99.8 \%$ is silicon dioxide, which is in turn a dominant substance in sandstone and thus environmentally friendly [79]. So far, the three most common forms of NPs used in EOR can be grouped into nanofluid, nanoemulsion, and nano-foam categories. By definition, nanofluid is a fluid containing dispersed NPs, forming a colloidal suspension. Nanoemulsion is a biphasic dispersion of two immiscible liquids: either water in oil (W/O) or oil in water $(\mathrm{O} / \mathrm{W})$ droplets stabilized by $\mathrm{NPs}$, also known as Pickering emulsion. For the case of NP-stabilized gas bubbles in a liquid, it is called nano-foam. In contrast to the nanofluid flooding, nanoemulsion and nano-foam often combine the use of existing EOR methods and NPs. The three major types of NPs for nanoemulsion and nano-foam are functionalized NPs synergized with surfactants, in-situ surface-activated NPs, and ex-situ surface-activated NPs. The most prevailing such NPs are silica-based, of which the surface hydroxyl content can be tuned to make them either hydrophilic or hydrophobic, leading to $\mathrm{O} / \mathrm{W}$ and $\mathrm{W} / \mathrm{O}$ emulsions, respectively.

Numerous laboratory experiments on nano-EOR have been carried out in the past decade [46]. Most research interests have been aroused by nanofluid flooding. Therefore, Table 2 summarizes the representative experimental research on nanofluid flooding that has been reported. Various types of NPs such as fullerenes, graphene, CNTs, polymers, and metallic and metal oxides have been studied, all presenting promising results in improved oil recovery. In addition, Table 3 details reported case studies using nanoemulsion and nano-foam, including the surface-coating, influencing factor, and resulting emulsion/foam type. Different types of nanomaterials have been proven to have unique properties that give various effects towards the porous media and the fluids [80]. Therefore, the following section will elaborate upon the specific nanomaterials that have been explored for EOR.

Table 2. Summary of the reported experimental studies on nanofluiding flooding.

\begin{tabular}{|c|c|c|c|c|c|}
\hline NP Type & $\begin{array}{l}\text { Concentration } \\
\quad(w t \%)\end{array}$ & $\begin{array}{l}\text { Additional } \\
\text { RF (\%) }\end{array}$ & Fluids & Porous Media & References \\
\hline $\mathrm{SiO}_{2}$ & $0.02-0.03$ & - & Water & sandstone core & [3] \\
\hline $\mathrm{FeO}, \mathrm{CuO}, \mathrm{NiO}$ & 5 & 14 & Water & carbonate core & [81] \\
\hline $\begin{array}{c}\mathrm{Al}_{2} \mathrm{O}_{3}, \mathrm{Ni}_{2} \mathrm{O}_{3}, \mathrm{MgO}, \\
\mathrm{Fe}_{2} \mathrm{O}_{3}, \mathrm{ZnO}, \mathrm{ZrO}_{2} \\
\mathrm{SnO}, \mathrm{SiO}_{2}\end{array}$ & 0.3 & 12 & $\begin{array}{c}\text { ethanol brine \& } \\
\text { water }\end{array}$ & sandstone core & [12] \\
\hline HLP \& $\mathrm{LHP} \mathrm{SiO}_{2}$ & $0.1-0.4$ & 19.31 & ethanol & sandstone core & [82] \\
\hline $\mathrm{SiO}_{2}$ & 0.1 & 10 & polyacrylamide & glass bed & [83] \\
\hline LHP $\mathrm{SiO}_{2}$ & $0.01-0.1$ & 10 & brine $(\mathrm{NaCl} 3 \mathrm{wt} \%)$ & Berea sandstone & [84] \\
\hline $\mathrm{TiO}_{2}$ & 0.01 and 1 & 51 & brine $(\mathrm{NaCl} 0.5 \mathrm{wt} \%)$ & sandstone core & [85] \\
\hline $\mathrm{Fe}_{2} \mathrm{O}_{3}, \mathrm{Al}_{2} \mathrm{O}_{3}$, silane & $0.05-0.3$ & 22.5 & propanol & sand pack & [86] \\
\hline $\mathrm{Al}_{2} \mathrm{O}_{3}, \mathrm{TiO}_{2}, \mathrm{SiO}_{2}$ & 0.05 & $7-11$ & brine $(\mathrm{NaCl} 3 \mathrm{wt} \%)$ & sandstone core & [87] \\
\hline $\mathrm{SiO}_{2}$ & 1 & 21 & $\begin{array}{l}\text { surfactant and } \\
\text { polymer }\end{array}$ & Berea sandstone & [88] \\
\hline $\mathrm{SiO}_{2}$ & $0.01-3$ & 29 & Water & sandstone core & [89] \\
\hline Nanoclay & 0.9 & 5.8 & Water & sandstone core & [90] \\
\hline $\begin{array}{c}\mathrm{ZrO}_{2}, \mathrm{TiO}_{2}, \mathrm{MgO}, \\
\mathrm{Al}_{2} \mathrm{O}_{3}, \mathrm{CeO}_{2}, \mathrm{CNT} \\
\mathrm{CaCO}_{3}, \mathrm{SiO}_{2}\end{array}$ & 5 & $8-9$ & brine (3-12 wt \%) & sandstone core & {$[80]$} \\
\hline $\mathrm{TiO}_{2}$ & $1.9-2.5$ & 4 & polymer and water & sandstone core & [91] \\
\hline MWCNT & $0.01-0.10$ & 31.8 & MWCNT fluid & glass bed & [92] \\
\hline $\mathrm{SnO}_{2}$ & 0.1 & 22 & Brine & carbonate core & [93] \\
\hline Complex nanofluid & 1 & $16-21$ & $\begin{array}{l}\text { water, brine, } \\
\text { surfactant }\end{array}$ & Tensleep core & [94] \\
\hline
\end{tabular}


Table 3. Summary of the reported experimental studies on nanoemulsion and nano-foam.

\begin{tabular}{|c|c|c|c|c|c|}
\hline NP Type & Surface Coating & $\begin{array}{l}\text { Concentration } \\
\quad(w t \%)\end{array}$ & $\begin{array}{l}\text { Influencing } \\
\text { Factor }\end{array}$ & $\begin{array}{l}\text { Emulsion/Foam } \\
\text { Type }\end{array}$ & References \\
\hline $\mathrm{SiO}_{2}$ & $\begin{array}{l}\text { Hydrophilic } \\
\text { Hydrophobic }\end{array}$ & $0.05-5$ & NP wettability & $\begin{array}{l}\text { decane-in-water } \\
\text { water-in-decane }\end{array}$ & [95] \\
\hline Fumed $\mathrm{SiO}_{2}$ & Neutral-wet & $0.1-5$ & Concentration & $\mathrm{W} / \mathrm{O}$ or $\mathrm{O} / \mathrm{W}$ & [96] \\
\hline Polystyrene & Carboxy-coated & 2 & Brine salinity & $\mathrm{W} / \mathrm{O}$ or $\mathrm{O} / \mathrm{W}$ & [97] \\
\hline $\mathrm{SiO}_{2}$ & Different $\mathrm{SiOH}$ & 1 & $\mathrm{SiOH}$ coverage & $\mathrm{CO}_{2}$-in-water & [98] \\
\hline $\mathrm{SiO}_{2}$ & Silylating agent & $0.9-2.4$ & $\mathrm{CO}_{2}$ density & Water-in- $\mathrm{CO}_{2}$ & [99] \\
\hline $\mathrm{SiO}_{2}$ & $\begin{array}{l}\text { Hexadecyltrimethoxysilane } \\
\text { and polyvinyl alcohol }\end{array}$ & 3 & - & $\mathrm{O} / \mathrm{W}$ & [100] \\
\hline $\mathrm{SiO}_{2}$ & $\begin{array}{l}\text { sodium dodecyl sulfate } \\
\text { and cetyl trimethyl } \\
\text { ammonium bromide }\end{array}$ & $0.1-0.5$ & $\begin{array}{l}\text { Concentration, } \\
\text { surfactant }\end{array}$ & $\mathrm{O} / \mathrm{W}$ & [101] \\
\hline $\begin{array}{l}\mathrm{SiO}_{2} \\
\text { Clay }\end{array}$ & $\begin{array}{c}\text { Hydrophilic } \\
\text { Partially hydrophobic }\end{array}$ & 1 & NP type & $\mathrm{O} / \mathrm{W}$ & [102] \\
\hline $\mathrm{SiO}_{2}$, clay & $\begin{array}{l}\text { Alpha-olefin sulfonate, } \\
\text { sodium dodecyl sulfate } \\
\text { and betaine }\end{array}$ & $500 \mathrm{ppm}$ & $\begin{array}{l}\text { Surfactant, NP } \\
\text { type }\end{array}$ & $\mathrm{CO}_{2}$-in-water & [103] \\
\hline $\mathrm{AlOOH}$ & $\begin{array}{l}\text { Sodium cumenesulfonate } \\
\text { (SC) }\end{array}$ & 1 & $\begin{array}{c}\text { SC } \\
\text { concentration }\end{array}$ & $\mathrm{CO}_{2}$-in-water & [104] \\
\hline $\mathrm{SiO}_{2}$ & Partially hydrophobic & $0-2$ & Surfactant & Gas-in-water & [105] \\
\hline $\mathrm{AlOOH}$ & Sodium dodecyl sulfate & 1 & Surfactant & $\mathrm{N}_{2}$-in-water & [106] \\
\hline $\mathrm{SiO}_{2}$ & Three wetting states & $5000 \mathrm{ppm}$ & $\begin{array}{l}\text { NP wetting } \\
\text { state }\end{array}$ & $\mathrm{CO}_{2}$-in-water & [107] \\
\hline $\mathrm{SiO}_{2}$ & Hydrophilic & 0.5 & $\begin{array}{c}\text { Four } \\
\text { surfactants }\end{array}$ & $\mathrm{CO}_{2}$-in-water & [108] \\
\hline
\end{tabular}

\subsection{Silica-Based}

Silica-based NPs are among the most often studied for EOR application since they can be produced easily, have well-known physical-chemical properties, and can be engineered with different characteristics such as hydrophobicity to hydrophilicity [79]. They are also one of the most abundant non-toxic inorganic materials [109] and have lower production costs than other NPs [110]. Many types of engineered silica NPs have been synthesized. These can be categorized based on their wettability behavior into three types [9]: lipophobic and hydrophilic polysilicon (LHP), hydrophobic and lipophilic polysilicon (HLP), and neutral-wet polysilicon (NWP). Silica-based NPs have been proved to change the wettability of porous media when adsorbed. In addition, silica NP itself has good thermal stability, as observed using infrared spectroscopy, $\mathrm{x}$-ray diffraction, and SEM analysis, excluding the thermal instability for relatively high temperature applications [111].

Ju et al. [3] conducted experimental and theoretical studies on the utilization of hydrophilic silica NPs (LHP) for EOR. By injecting 2.0-3.0\% of LHP NPs, they concluded that NPs could be adsorbed onto pore walls, changing the wettability of the surface and apparently improving the oil recovery. Onyekonwu and Ogolo [12] performed a further study on LHP, HLP, and NWP silica NPs dispersed in different fluids (water, ethanol, and alcohol). NWP and HLP silica NPs dispersed in ethanol could alter the wettability of the water-wet core and behave as surfactants by reducing the oil-water interfacial tension. Hendraningrat et al. [84] studied the effect of LHP silica NPs by implementing a coreflood experiment on the Berea sandstone core with various NP concentrations from 0.01 up to $0.1 \mathrm{wt} \%$ dispersed in brine $(\mathrm{NaCl} 3.0 \mathrm{wt} \%)$. They showed that the contact angle decreases when the concentration of NPs increases, but a higher concentration tends to block the pore throat of the low-permeability Berea core sample. Moreover, earlier nanofluid injection is favorable since it gives the highest ultimate oil recovery compared to the post-waterflood and sequenced water-nanofluids 
injection scenario [82]. For application in heavy oil recovery, silica NPs dispersed in brine in a carbonate core sample improved recovery by $39 \%$ to $61 \%$ [93].

A combination of silica NPs with a polymer for EOR was also studied. Maghzi et al. [112] dispersed silica NP into a polymer (polyacrylamide) solution in a glass micromodel to study the rheology of a polyacrylamide solution when silica NPs are present in the mixture. By applying $0.1 \mathrm{wt}$ $\%$ of silica NP to the mixture, the pseudo-plasticity of the polymer solution was improved at a low shear rate and the overall viscosity of the mixture increased, which led to up to $10 \%$ additional oil recovery. Sharma et al. [88] studied the utilization of silica NPs dispersed in a polymer and surfactant mixture for chemical EOR and found that silica NPs could lower and stabilize the interfacial tension for a Pickering emulsion, leading to $21 \%$ additional recovery compared to conventional surfactant-polymer flooding. The efficiency of a conventional polymer and surfactant-polymer flood is reduced when the temperature increases. By contrast, the nanofluid mixture exhibits stable behavior at higher temperatures, making it a potential solution for high-temperature chemical EOR [113,114].

Several problems such as viscous fingering, channeling, and poor sweep efficiency are often experienced during conventional $\mathrm{CO}_{2}$ flooding [115]. Therefore, the formation of a $\mathrm{CO}_{2}$-in-water foam was proposed to handle those problems [116]. AttarHamed et al. [117] investigated the effect of hydrophobic silica NP in $\mathrm{CO}_{2}$-water foam by varying the size and concentration of NPs. They demonstrated that in a low concentration of NPs, a bigger NP size was favored for foam stability; while in a high concentration, a smaller NP size was preferred. More recently, Kim et al. [118] were able to synthesize stable $\mathrm{CO}_{2}$-in-brine and decane-in-brine foam with smaller-sized silica NPs.

Silica NP is considered to be the most economical and environmentally friendly NP, even though the risk of dry silica NP should be assessed since it could be dangerous to humans when directly inhaled [87].

\subsection{Aluminum Oxides}

Aluminum oxide $\left(\mathrm{Al}_{2} \mathrm{O}_{3}\right)$ NPs can be fabricated by several processes such as flame spray pyrolysis [119], modified plasma arc [120], and mechanochemical methods [121]. Ogolo et al. [122] reported that $\mathrm{Al}_{2} \mathrm{O}_{3} \mathrm{NPs}$ with an average size of $40 \mathrm{~nm}$ dispersed in water and brine exhibited higher additional oil recovery (12.5\%) than other metal oxide NPs. Giraldo et al. [123] investigated the adsorption of $\mathrm{Al}_{2} \mathrm{O}_{3}$-based NPs that could alter wettability through their coating mechanism. Dispersing $\mathrm{Al}_{2} \mathrm{O}_{3} \mathrm{NPs}$ in an anionic surfactant with a concentration from 0.01 to $1.00 \mathrm{wt} \%$, they observed that $\mathrm{Al}_{2} \mathrm{O}_{3}$ NPs and a surfactant solution could alter the wettability of rock from a strong oil-wet to strong water-wet surface, as proved by the change of residual water saturation $\mathrm{S}_{\mathrm{wr}}$ from 0.07 to 0.23 (Figure 2).

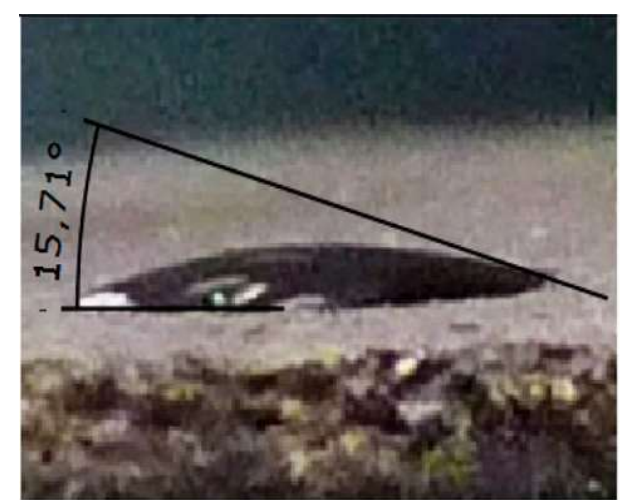

(a)

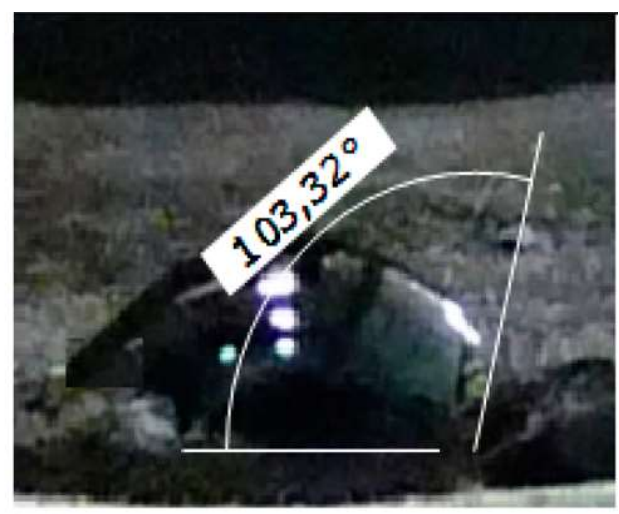

(b)

Figure 2. Oil-air contact angle on rock surface before (a) and after (b) being treated with $100 \mathrm{ppm} \mathrm{Al}_{2} \mathrm{O}_{3}$ NPs. Reproduced with permission from reference [124]. Copyright 2013 American Chemical Society. 
Zaid et al. [124] investigated the effect of $\mathrm{Al}_{2} \mathrm{O}_{3}$ NPs dispersed in an aqueous surfactant (sodium dodecyl sulfate). Using two different kinds of $\mathrm{Al}_{2} \mathrm{O}_{3} \mathrm{NPs}$ (sol-gel and commercial product), they could achieve up to $53.5 \%$ of remaining oil. Interestingly, commercial $\mathrm{Al}_{2} \mathrm{O}_{3}-\mathrm{RM}$ (commercial) achieved $63 \%$ more oil than $\mathrm{Al}_{2} \mathrm{O}_{3}$-SG (sol-gel), even though the $\mathrm{Al}_{2} \mathrm{O}_{3}$-SG yields a lower interfacial tension (IFT) with a smaller size. This suggests that lower IFT does not always lead to higher recovery since other factors such as sweep efficiency and fluid rheology are also important.

Hendraningrat et al. [2,87] studied the potential of aluminum, titana, and silica NPs in a two-phase coreflooding process on the Berea core plug. Polyvinylpyrrolidone (PVP) dispersant was added to stabilize the nanofluid in light of the natural tendency of NPs to aggregate into bigger ones. Coreflood experiment results showed that the additional oil recovery was higher for other metal oxide NPs than for silica NPs (especially in water-wet system), since other metal oxides are adsorbed into the pore surface more easily than silica [2]. In addition, even though titania presented a larger contact angle reduction (up to $54^{\circ}$ ) between oil-water and rock, alumina still proved to be a good candidate for EOR. Similar experiments using silica, alumina, and iron oxides diluted in propanol solution proved that alumina has better results in oil displacement than iron oxide, with a similar effect to silica NPs [86]. Alomair et al. [125] indicated that mixed alumina and silica NPs at a $0.05 \mathrm{wt} \%$ concentration resulted in the highest amount of recoverable oil. They suggested using a combination of alumina and silica NPs for handling harsh reservoir conditions (high temperature, salinity, and pressure) and for controlling asphaltene precipitation.

\subsection{Iron Oxide}

With unique magnetic and electrical properties, iron oxide $\left(\mathrm{Fe}_{2} \mathrm{O}_{3} / \mathrm{Fe}_{3} \mathrm{O}_{4}\right)$ NPs have been proposed as nano sensors [126]. However, there are only a few studies on the potential use of iron oxides for EOR. Haroun et al. [81] studied several metal oxide NPs such as $\mathrm{Fe}_{2} \mathrm{O}_{3}, \mathrm{CuO}$, and $\mathrm{NiO}$ on carbonate core plugs. The result for the iron oxide NPs was not so promising since it could only reach $57 \%$ ultimate recovery while other NPs could achieve up to $85 \%$. However, others have shown that iron oxide NPs were able to increase recovery up to $24 \%$ (additional) when dispersed in water [122]. They can increase the viscosity of the displacing fluid, which leads to a higher sweep efficiency. Joonaki et al. [86] reported that iron oxides were only able to recover $17 \%$ extra oil while other NPs (i.e., $\mathrm{Al}_{2} \mathrm{O}_{3}$ and $\mathrm{SiO}_{2}$ ) recovered around $20 \%$ additional oil.

Ferrofluids $\left(\mathrm{Fe}_{3} \mathrm{O}_{4}\right)$ were proposed for magnetic heavy oil recovery by Shekhawat et al. [127]. The magnetic recovery mechanism works by having an in-situ injection of magnetic NPs and pushing the NPs toward the reservoir using a repelling magnetic force from downhole tools. Then, inward magnetic forces are applied toward the borehole to attract and recover the magnetic NPs that are already soaked with oil.

\subsection{Nickel Oxide}

As a hydrophilic metal oxide $\mathrm{NP}$, nickel oxide $\left(\mathrm{NiO} / \mathrm{Ni}_{2} \mathrm{O}_{3}\right) \mathrm{NP}$ has a potential use for EOR [122,128]. $\mathrm{NiO}$ is not superior to other metal oxides $\left(\mathrm{Al}_{2} \mathrm{O}_{3}\right.$ and $\left.\mathrm{ZrO}_{2}\right)$ for EOR, but it still gave a positive improvement in recovery with its ability to alter wettability and enhance viscosity. For example, Ogolo et al. [122] found that nickel oxide NPs dissolved in diesel and brine had a positive effect for improving oil recovery due to wettability alteration of the rock surface and viscosity enhancement of the brine. Nwidee et al. [129] studied the effect of $\mathrm{NiO}$ and $\mathrm{ZrO}_{2} \mathrm{NPs}$ on fractured limestone core samples. Even though $\mathrm{ZrO}_{2}$ gave a better result, $\mathrm{NiO}$ has potential use as an EOR agent because it is able to reduce the water contact angle with increasing concentration, injection time, and salinity.

\subsection{Titanium Oxide}

The potential use of titanium oxide $\left(\mathrm{TiO}_{2}\right)$ NPs for EOR has been proposed by several researchers. Ehtesabi et al. [130] employed $\mathrm{TiO}_{2} \mathrm{NPs}$ in water to enhance oil recovery in a sandstone core plug and 
discovered that $\mathrm{TiO}_{2} \mathrm{NPs}$ could improve recovery from $49 \%$ to $80 \%$ by altering the wettability due to uniform adsorption, as proved by an SEM study. Similar experiments with lower concentrations of $\mathrm{TiO}_{2}$ NPs (0.01 and $0.05 \mathrm{wt} \%$ ) [85] revealed that $\mathrm{TiO}_{2}$ did not affect viscosity and interfacial tension but did change the wettability from oil-wet to water-wet. Hendraningrat et al. [87] studied the effect of $\mathrm{Al}_{2} \mathrm{O}_{3}$ and $\mathrm{TiO}_{2}$ on the Berea sandstone and showed that a combination of $\mathrm{TiO}_{2} \mathrm{NPs}$ with PVP as the dispersant yielded the highest recovery compared with $\mathrm{Al}_{2} \mathrm{O}_{3}, \mathrm{SiO}_{2}$, brine-only, and dispersant-only. They concluded that $\mathrm{TiO}_{2} \mathrm{NP}$ is the most effective NP for EOR compared to the other metal oxide NPs, with wettability alteration as the dominant mechanism [2].

The possibility of combining $\mathrm{TiO}_{2} \mathrm{NPs}$ with surfactants or polymers in chemical EOR has also been investigated. Cheraghian et al. [91] showed that oil recovery increased by $4.85 \%$ when using $2.2 \mathrm{wt} \%$ $\mathrm{TiO}_{2}$ in surfactant solution compared to pure surfactant. Similarly, by combining a polymer with $2.3 \mathrm{wt} \% \mathrm{TiO}_{2}$, the recovery of oil was improved by $3.9 \%$ compared to conventional polymer flooding due to the viscosity improvement of the displacing fluid [131]. Moreover, Sedaghat et al. [132] observed an effect of $\mathrm{TiO}_{2}$ on polymer-surfactant flooding which showed positive recovery improvement compared to conventional polymer-surfactant flooding.

\subsection{Zinc Oxide}

Zinc oxide $(\mathrm{ZnO})$ has been widely studied for wettability change in EOR in the past few years. Zaid et al. [124] proved that $\mathrm{ZnO}$ has a better performance in oil recovery than $\mathrm{Al}_{2} \mathrm{O}_{3}$ (72\% ROIP for $\mathrm{ZnO}$ vs. $53 \%$ for $\mathrm{Al}_{2} \mathrm{O}_{3}$ ) with lower IFT values. They found that a larger particle size of $\mathrm{ZnO}$ gives about a $145 \%$ higher recovery than smaller sizes. Similarly, Tajmiri et al. [133] investigated oil recovery by $0.2 \mathrm{wt} \% \mathrm{ZnO}$ NPs over heavy oil-saturated sandstone and carbonate core samples. Improved oil recovery with both carbonate ( $8.89 \%$ of OOIP) and sandstone (up to $20.68 \%$ OOIP) core plugs was achieved. ZnO NP was able to reduce the viscosity of heavy oil and alter the wettability of the grain surface. Latiff et al. [134] successfully recovered $26 \%$ of the remaining oil in a glass micromodel saturated with heavy oil (viscosity $12.31 \mathrm{cP}$ ) through $30 \mathrm{~min}$ of electromagnetic (EM) exposure with a simultaneous $\mathrm{ZnO}$ nanofluid injection.

However, Ogolo et al. [12] found that $\mathrm{ZnO}$ dispersed in brine and water caused permeability reduction due to the agglomeration of ZnO NPs into larger particles, which blocked the pore throats of the core. Since stability is one of the key factors for a successful EOR application, Adil et al. [135] performed further studies on the stability of $\mathrm{ZnO} N$ Ps dispersed in water by using different anionic surfactants as stabilizers with various NPs concentrations. They found that $0.1 \mathrm{wt} \% \mathrm{ZnO}$ NPs stabilized with $0.025 \mathrm{wt} \%$ sodium dodecyl benzenesulfonate (SDBS) have the highest stability at $95^{\circ} \mathrm{C}$ with viscosity enhancement up to $11 \%$. The combination of surfactant, $\mathrm{pH}$, and ultrasonication for $\mathrm{ZnO}$ nanofluid preparation was also suggested to affect the nanofluid mobility properties.

\subsection{Zirconium Oxide}

Zirconium oxide, or zirconia $\left(\mathrm{ZrO}_{2}\right)$ NPs are widely used in catalysis, ceramics, thermal coating, etc. [126]. Karimi et al. [136] applied in-house prepared $\mathrm{ZrO}_{2}$ NPs dispersed in nonionic surfactant for EOR. They found that $\mathrm{ZrO}_{2}$ NPs could change the wettability of the carbonate core from strong oil-wet to strong water-wet through the adsorption of NPs onto a carbonate surface confirmed by an SEM image. However, the wettability alteration process by $\mathrm{ZrO}_{2} \mathrm{NPs}$ (adsorption and growth) was a slow process, taking approximately two days. Recently, Nwidee et al. [129] investigated the wettability alteration on carbonate core samples by means of $\mathrm{ZrO}_{2} \mathrm{NP}$ injection. The water contact angle decreased with increased concentration, salinity, and exposure times. Combining $\mathrm{ZrO}_{2} \mathrm{NPs}$ and a surfactant could achieve better results in wettability alteration for carbonate rock [137] because a cationic surfactant can form ion pairs with the cationic head and the acidic component of the crude, while NPs will develop a continuous wedge film around the liquid-solid surface. Moreover, interfacial tension between two fluids can be considerably reduced by $\mathrm{ZrO}_{2}$ [138], and a higher adsorption energy is needed for the oil-water interface than the air-water interface. 


\subsection{Polymer and Polymer-Coated}

Polymers are mainly used as stabilizers or coating materials to improve the stability of nanofluids [87]. Nanoparticles with at least one polymer as a component are considered polymer NPs (PNP) [139]. PNP can be fabricated from pre-formed polymers or the direct polymerization of monomers. Several processes such as solvent evaporation, salting-out, and dialysis are used for preparing PNP from pre-formed polymers. PNP can also be directly fabricated by the polymerization of monomers by various methods such as mini-emulsion, micro-emulsion, surfactant-free emulsion, and interfacial polymerization [140]. PNPs are thought to improve mobility control and wettability alteration during the EOR process [141].

Nano-sized polymers for EOR have been studied to improve the injection efficiency and reduce the injection cost [1]. Wang et al. [142] conducted an experimental study on the effect of polyacrylamide (PAM) microgel nanospheres on recovery improvement and were able to recover $20 \%$ additional heavy oil. PAM nanospheres could enhance the viscosity of the nanofluid and improve the sweep efficiency of the EOR [142]. However, more research needs to be done for PNP since few studies are reported on the potential of polymer and polymer-coated NPs as EOR agents.

\section{9. $C N T$}

CNT is a cylinder-shaped carbon structure within a nano-size range. It was discovered by lijima in 1991 [143] and classified as a fullerene type [126]. The two most common CNTs that have been used in various studies are the single-walled CNT (SWCNT) and multi-walled CNT (MWCNT) [126]. Little research has been conducted on CNTs for EOR since this type of material is relatively new [126] and not yet economical to apply on a field scale. However, CNTs possess unique structural and electronic properties [144], as well as a hydrophobic nature.

Shen and Resasco [144] reported that the stability of water-oil emulsion was increased in the presence of CNT/silica nanohybrid NPs. The resulting emulsion can handle coalescence and sedimentation, and can be separated easily by filtration or centrifugation processes. Similarly, Villamizar et al. [145] flooded an SWCNT-silica nanohybrid solution into a glass bed with crushed Berea sand and found that although more energy was needed for injecting the emulsion into the sand packs, the NP could effectively improve recovery through an interfacial active catalytic reaction. Kadhum et al. [146] flooded MWCNT into both Berea core plugs and sand packs and saw an improved dispersion stability and propagation in high temperature and salinity conditions. The NP retention was dependent on oil saturation, with more than $80 \%$ NP found in the effluent. Alnarabiji et al. [92] found that using MWCNT-based nanofluid resulted in 31.8\% additional recovery of heavy crude oil. AfzaliTabar et al. [147] conducted a comparative study on the performance of MWCNT, SWCNT, and activated carbon for the application of a Pickering emulsion in chemical EOR. The emulsions were formulated at $\mathrm{pH}$ of 7 with distilled water. The Pickering emulsion using MWCNT exhibited the highest stability at $0.1 \%$ and $1 \%$ salinity and moderate temperature $\left(25\right.$ to $\left.90^{\circ} \mathrm{C}\right)$, and it successfully altered the wettability of oil-wet carbonate rock into water-wet.

To summarize, some NP types such as silica, alumina, titanium oxide, and zinc oxide were proven to be potential EOR agents through wettability alteration and IFT reduction mechanisms. However, others such as nickel oxide, zirconium oxide, and iron oxide NPs, have shown relatively decent results in terms of the recovery improvement. There are also possibilities of combining several NPs which could potentially enhance the oil recovery. Thus, further research on nano-EOR needs to be done with varied NPs to uncover the potentials and improve the understanding on the mechanisms.

\section{Parameters Affecting Nano-EOR}

\subsection{NP Size}

The size and charge density of NPs have a significant effect on the strength of the disjoining pressure. For a similar mass, smaller NPs will give a higher particle density and lower contact angle 
between the fluid and the rock surface. A higher particle density improves the structural disjoining pressure (see Section 5.3) significantly [148]. For less hydrophilic surfaces, smaller NPs will spread more readily than bigger particles. McElfresh et al. [149] concluded that smaller particles would result in a higher charge density and stronger electrostatic repulsion, assuming the particle is stable.

According to Hendraningrat et al. [150], smaller particles have been proven to not only increase oil recovery considerably, but also improve the displacement efficiency. Several other experiments concluded that smaller particles would lead to higher ultimate oil recovery [89]. Kondiparty et al. [148] proved that decreasing the NP diameter from $30 \mathrm{~nm}$ to $18.5 \mathrm{~nm}$ increased the structural disjoining pressure about 4.3 times. The size of the particle should be small enough that it cannot be mechanically trapped, but big enough to avoid extra log-jamming [89]. Therefore, smaller particles are often preferable for higher oil recovery [109]. It should be noted that the high surface energy could result in severe agglomeration and surface adsorption of the ultrafine NPs, affecting the stability of the nanofluid. Furthermore, the NP size also affects the surface coating process. Therefore, we assume that there should be an optimal value with respect to the NP size.

\subsection{NP Concentration}

The concentration of injected NPs is one of the key parameters that determine the EOR process. According to Chengara [151], disjoining pressure will increase with increasing concentration, which also increases the repulsion forces. Increasing concentration will also improve the displacement efficiency due to the enhanced viscosity of the nanofluid and the spreading of NPs on the grain surface [89]. The interfacial tension between reservoir fluids can be decreased significantly by increasing the concentration of injected NPs [152]. A high concentration also leads to a higher wettability alteration effect. In light of this, a higher concentration is favorable for higher oil recovery.

However, there is a limit to the concentration of injected NPs, and above that limit, NPs will tend to block the pore throat and reduce the ultimate oil recovery. A higher concentration will improve the displacement efficiency, wettability alteration, and IFT reduction. However, when the concentration is too high, the aggregated NPs will accumulate around the inlet and reduce the displacement efficiency [109]. Hendraningrat et al. [152] reported that the permeability and porosity of a Berea core was impaired by about $2 \%$ after injecting silica NPs with a concentration above $0.5 \mathrm{wt} \%$. Thus, an optimum injected concentration is necessary to get maximum oil recovery. However, this optimum concentration varies depending on the type of nanoparticle, porous medium, and environmental conditions.

\subsection{Salinity}

The salinity of the displacing nanofluids and the reservoir fluids has a significant effect on the stability of the dispersion. Increased salinity reduces the zeta potential of the particles, which leads to easy agglomeration [149]. High ionic strength in the fluid due to the presence of salt will lead to lower electrical repulsion between particles and allows the vdW attraction forces to dominate. As most of the rock surface is charged, it is expected that the attraction and collision will happen for particle-particle but not particle-surface [153]. Thus, in a high-salinity environment, modification to the NPs is necessary to maintain the stability which can be achieved by surface modification, ionic control via a surfactant, or a combination of both [89]. Worthen et al. [154] reported the stabilization of NPs by anchoring low molecular weight ligands to the NP surface in a high-salinity environment. The authors claimed that the NP stabilization stems from the steric hindrance.

On the other hand, by using high-stability silica NPs, Hendraningrat et al. [109] proved that high salinity nanofluid injection could alter the rock wettability to be more water-wet. At high salinity, the adsorption of NPs is improved due to increasing physicochemical interactions [155]. Similarly, Kanj et al. [156] concluded from their research that increasing the salinity of the fluid did not hinder the transport of NPs but did increase the adsorption on the grain surface. Increasing salinity seems to increase the adsorption of NPs and improve the recovery of the oil. However, at the same time, 
the stability of NPs will be reduced in a high-salinity environment. Therefore, the appropriate salinity level and surface modification are important aspects to be considered to prevent the agglomeration of NPs.

\subsection{Reservoir Temperature}

Since the temperature of the reservoir is always higher than the temperature at the surface, nanofluids should be able to operate at relatively high temperatures for effective nano-EOR application [89]. According to Caldelas [157], temperature has an insignificant effect on NP retention due to weak temperature dependence for the adsorption and desorption of NPs. By contrast, Hendraningrat et al. [150] stated that temperature significantly influences oil recovery. A higher temperature is preferred for greater oil recovery, since it will alter the reservoir fluids at the molecular level, which reduces the contact angle between the fluids.

However, the mechanism of the temperature effect is complex and difficult to explain since it involves several variables. For example, increasing the temperature tends to decrease the zeta potential of the particles. This means that the stability of the nanofluid will be decreased, which will likely reduce oil recovery due to agglomeration [149]. The increment of recovery could probably be ascribed to the decreased IFT at high temperature since it weakens molecular interaction or to the increased Brownian motion and reduced viscosity [150]. Since temperature will affect both nanofluids and the reservoir system, the effect of temperature on oil recovery cannot be generalized. Therefore, further study on the temperature effect should be performed to obtain a better understanding of its role in nano-EOR processes.

\subsection{Rock Wettability}

Increasing the water-wetness of the rock will increase oil recovery [158] and vice versa [159]. According to Morrow [159], strong water wetness and associated high capillary imbibition are favorable for more efficient oil displacement. However, in special cases, it has been reported that an oil-wet reservoir [160] and neutral wettability [161] offer higher oil recovery. Thus, wettability plays an important role in hydrocarbon mobility, affecting the distribution and displacement process of the hydrocarbon and other reservoir fluids within the matrix [5].

During nano-EOR, initial wettability will determine the magnitude of the wettability alteration. An experimental study using silica NPs showed that the highest incremental oil recovery was yielded from an intermediate-wet core [150]. In an intermediate-wet condition, oil and brine are in the equilibrium state, which reduces the possibility of a disconnected and trapped oil phase in the matrix [150]. Li et al. [4] added that wettability affects the adsorption of NPs. Water-wet and neutral-wet cores have a higher adsorption of NPs than oil-wet media. In an oil-wet medium, the adsorption area is very close to the desorption area, which means that desorption is likely to happen. In that case, the effect of NPs on the oil-wet rock will be diminished.

More advanced studies are needed to investigate the known and unknown parameters that could potentially affect the implementation of nano-EOR. Deeper understanding of both mechanisms and parameters is the key to success in real-world application of nanotechnology in EOR.

\section{Mechanism}

Several mechanisms for the improvement of oil recovery by NPs have been proposed, such as interfacial tension reduction, wettability alteration, viscosity control, and disjoining pressure. Those mechanisms take place because the adsorption, desorption, and transport of NP occur inside the pore throat [3]. Since the size of NP is very small $(1-100 \mathrm{~nm})$ compared to the grain and pore throat size, five types of energy will be responsible for their interaction with the pore surface: (1) London-van der Waals attractive potential energy; (2) electric double layer repulsion energy; (3) Born repulsion; (4) acid-base interaction; and (5) hydrodynamic energy [162]. Adsorption occurs when the attractive force is larger than the repulsion force, while desorption will happen otherwise. In addition, 
the transport of NPs inside the pore throat is driven by diffusion and convection. Blocking occurs due to the agglomeration of NPs into sizes larger than the pore throat [3].

\subsection{Wettability Alteration}

Wettability is defined as the tendency of a certain fluid to spread on the solid surface in the presence of other immiscible fluids in the same system [90]. It is directly related to the fluid-fluid and fluid-solid interactions, which indicate the interfacial energy between two immiscible phases [45]. In general, wettability is a rock property that depends on the type of minerals, pore distribution, and surface area. It is also a function of fluid composition and temperature [90].

Several studies have revealed that wettability is an important factor for understanding the multiphase flow during hydrocarbon accumulation until production and achieving the highest oil recovery $[159,163]$. Since wettability significantly affects capillary pressure and relative permeability, the oil flow inside the porous media can be improved considerably [45]. It also leads to the spontaneous imbibition of water that helps to push the hydrocarbon out of the matrix blocks during water flooding [123]. Surfactant flooding is a well-known method for altering wettability. However, using surfactants on a field scale is not very economical [164]. Therefore, many researchers have proposed nanoparticles as an alternative to wettability alteration agents.

Nanoparticles and surfactants work by similar mechanisms on wettability alteration [123]. Hammond and Unsal [165] proposed the two most possible mechanisms: adsorption on the solid surface (coating mechanism) and removal of the absorbed molecule from the rock surface (cleaning mechanism). The adsorption process of NPs on the grain surface results in the formation of a composite nanostructure-surface which improves the water-wetting behavior [136]. SEM images show the adsorption of silica NPs on a calcite surface, which forms a layer of the nanostructure with some agglomerated particles after one hour of nanofluid treatment [166]. The surface modification by nanoparticles also increases the roughness of the surface, as can be seen in Figure 3 [166]. Karimi et al. [136] added that the main factors in wettability alteration are the area fractions of the nanostructure, partition coefficient, and surface roughness.
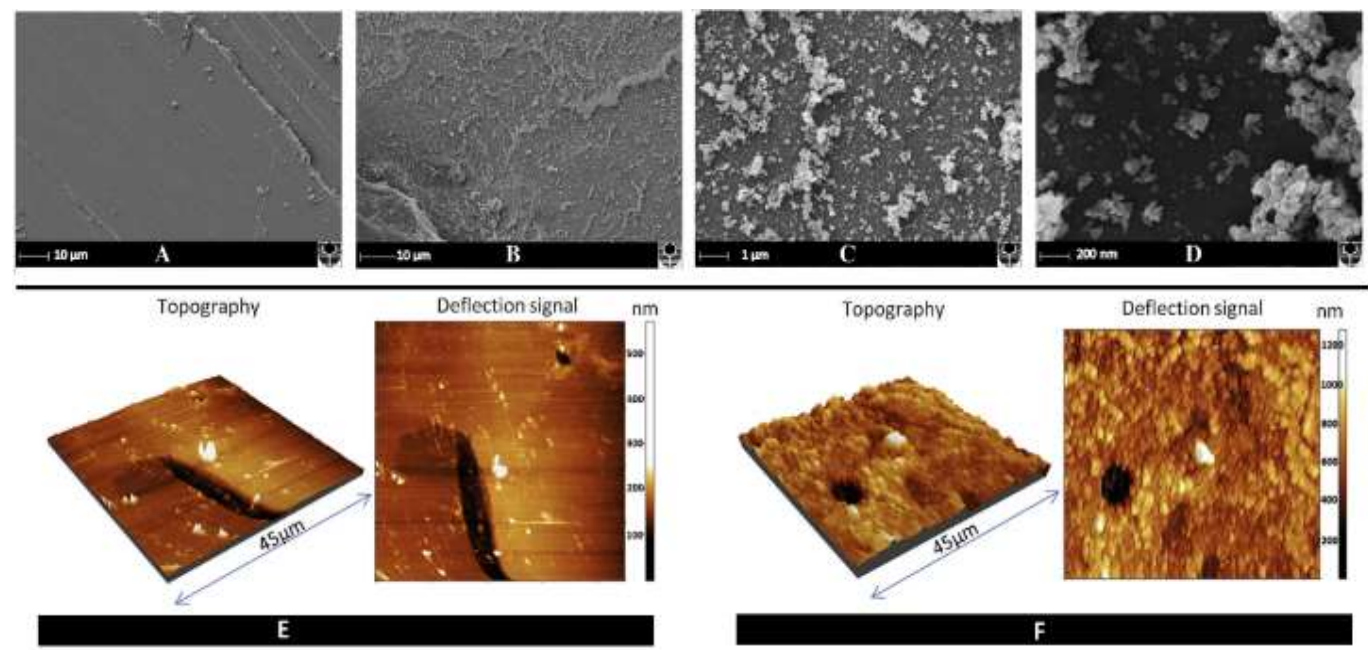

Figure 3. SEM and atomic force microscopy image of calcite surface. Calcite surface before (A) and after (B) nanofluid treatment; (C) High resolution; (D) Max resolution; Topography picture before (E) and after (F) nanofluid treatment. Reproduced with permission from reference [167]. Copyright 2016 Elsevier.

Moreover, Hendraningrat et al. [152] investigated the effect of LHP silica NPs on the wettability alteration of a polished-synthetic-silica surface in different concentrations. As shown in Figure 4, increasing concentrations of NPs will reduce the contact angle of crude oil and change the wettability 
toward more water-wet. They concluded that a smaller size of NPs tends to decrease the contact angle more than larger size particles due to the higher electrostatic repulsion of smaller sizes. Moreover, wettability alteration is a function of salinity, ionic composition, initial wettability, a solid system, and exposure time [167]. There is also evidence of NPs altering wettability in both carbonate [168] and sandstone rocks [4].
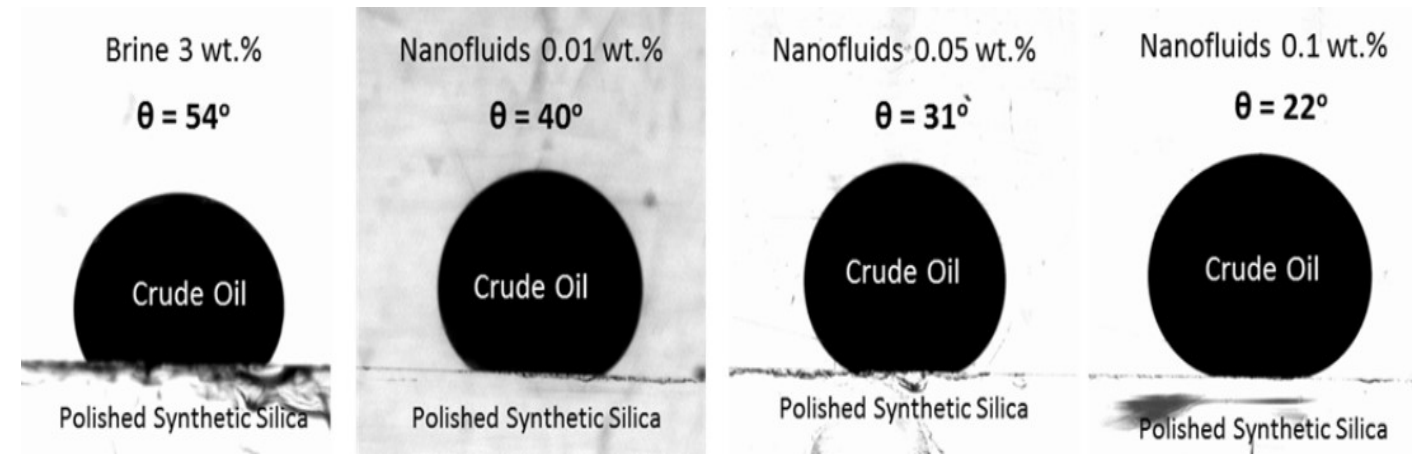

Figure 4. Contact angle variation of the oil-brine system in different concentrations. Reproduced with permission from reference [153]. Copyright 2013 Elsevier.

\subsection{Interfacial Tension Reduction}

Capillary force restricts oil recovery in a reservoir system [94]. The value of capillary force is determined by the IFT between the reservoir fluids and rock wettability [169]. By reducing the IFT and altering the rock wettability, the capillary pressure will decrease, leading to improved oil recovery [170]. IFT is usually measured with the pendant drop method [38] and the spinning drop method [4].

Decreasing the IFT by using a surfactant is an important mechanism for mobilizing residual oil [94]. Nanoparticles are proposed to assist in decreasing IFT during EOR processes with or without a surfactant. The presence of NPs in a surfactant mixture can improve the rheology of the solution and enhance the surfactant's effect on IFT reduction [171]. Adsorption of NPs onto the surface of the fluid will effectively reduce the IFT between those fluids [38].

The ability of silica NPs to reduce IFT has been demonstrated by several studies. Roustaie et al. [172] reported that NWP and HLP silica NPs were able to reduce the oil-water IFT from $26.3 \mathrm{mN} / \mathrm{m}$ to $2.55 \mathrm{mN} / \mathrm{m}$ and $1.75 \mathrm{mN} / \mathrm{m}$, respectively. Hendraningrat et al. [152] added that the magnitude of IFT reduction is directly related to the concentration of NPs, with a higher concentration favorable for lower IFT. In addition, alumina NPs dispersed in brine were able to reduce brine-oil IFT from $19.2 \mathrm{mN} / \mathrm{m}$ to $12.8 \mathrm{mN} / \mathrm{m}$, while silica-based NPs were only able to reduce it to $15.7 \mathrm{mN} / \mathrm{m}$ [2]. CNTs have also been proven to significantly reduce interfacial tension, demonstrating their potential for use as an EOR agent [147].

The presence of NPs in a surfactant mixture can improve the rheology of the solution and enhance the surfactant's effect on IFT reduction [171]. Adsorption of NPs onto the surface of the fluid will effectively reduce the IFT between those fluids [38]. Zirconium oxides mixed in a surfactant solution have been shown to significantly reduce the IFT of heptane-fluid and air-fluid [138]. Moghadam [173] found that zinc oxides could improve the efficiency of a sodium dodecyl sulfate (SDS) surfactant in reducing IFT. The $\mathrm{pH}$ of the fluid had a significant effect on IFT, with an acidic and neutral $\mathrm{pH}$ favored.

\subsection{Disjoining Pressure}

Disjoining pressure ( $\Pi d)$, defined as the attractive and repulsive forces between two thin layers of fluid surfaces [174], has been widely studied as one of the key mechanisms of nano-EOR [175,176]. Chengara et al. [151] specifically defined disjoining pressure in thin liquid film as the excess pressure in the film relative to that in the bulk solution. Nanofluids have been considered to significantly affect disjoining pressure between two immiscible fluids. 
The spreading and adhesion behaviors of nanofluids on a solid surface are quite complex. They are different from simple liquid behavior, since a three-phase contact region exists [177]. In three-phase regions, NPs dispersed in the liquid tend to develop wedge-shaped structures and forces toward the oil-solid contact area, as schematically shown in Figure 5A. Those ordered structures in the wedge film enhance the spreading and wetting strength of the nanofluid on the solid surface [178]. The force created by a single particle is relatively small, but the total forces of a large number of NPs can reach up to $5 \times 10^{4} \mathrm{~Pa}$ in the vertex region (Figure 5B) [4]. The mechanisms that drive this phenomenon are Brownian motion and electrostatic repulsion [177]. In short, the disjoining force is responsible for the detachment of oil from the solid surface while allowing the nanofluid to spread further.

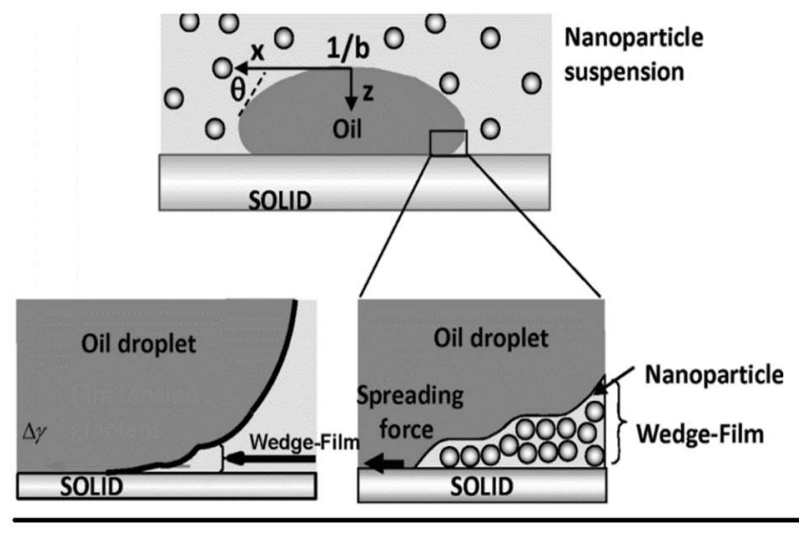

A

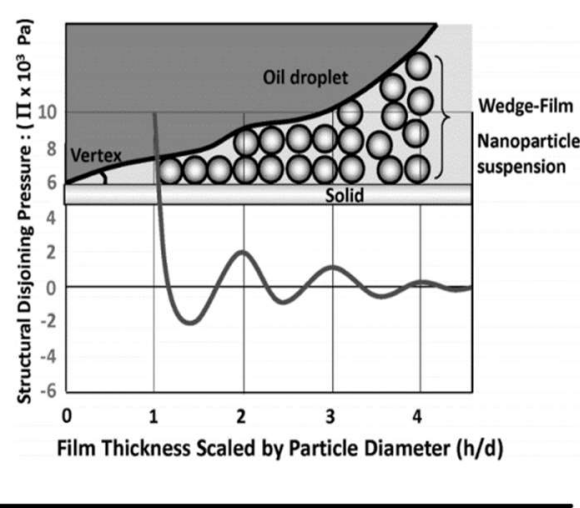

Figure 5. Wedge-shaped nanoparticle structure and forces (A) and wedge contact pressure (B). Reproduced with permission from reference. [149]. Copyright 2011 American Chemical Society.

Disjoining pressure is affected by several parameters, such as the nanoparticle size, concentration, charge density, temperature, salinity, and surface characteristics [149]. Kondiparty et al. [148] concluded that a higher concentration and smaller size of NPs will lead to increased disjoining pressure. Moreover, the force at the wedge film will increase when smaller sizes of NPs with a higher charge density and electrostatic repulsion are used [4]. However, polydispersity of the NPs needs to be considered since it could significantly affect the magnitude of the disjoining pressure [179].

\subsection{Viscosity Control}

During the EOR process, high mobility of the displacing fluid often results in viscous fingering, which leads to a poor sweep efficiency and conformance [13]. Thus, it is necessary to control the mobility of the injected fluid to achieve a better sweep efficiency for higher oil recovery. Polymer flooding has been successfully used as a viscosity control agent for increasing the sweep efficiency [180,181]. Nevertheless, in a reservoir with harsh conditions (high temperature, pressure, salinity, etc.), the polymer solution often becomes degraded, which will decrease its viscosity and sweep efficiency $[182,183]$. NPs have been proposed to enhance the viscosity of the polymers in the injection fluid because they improve the thermal stability of the polymer solution and prevent degradation.

Thickening of the solution occurs due to the ability of NPs to form a network structure via hydrogen bonding [184], which will directly affect the fluid shear stress [15]. Zeyghami et al. [184] showed that viscosity enhancement by silica NPs in a water solution is relatively low due to the high polarity of water. However, in the polymer solution, NPs seem to be able to enhance pseudoplasticity behavior considerably, even at a low shear rate $[83,185]$. Moreover, they prevent premature degradation of the polymer in high salinity conditions by preventing polymers from interacting with ions and can be substituted for polymers to attract cations [83].

Maghzi et al. [83] investigated the effect of the dispersion of silica NP on polymer flooding at different levels of fluid salinity. As shown in Figure 6, by adding silica NP in the polymer 
solution, degradation can be significantly reduced. The trapped oil can be efficiently mobilized by increasing the concentration of NPs. A comparison of different injection fluids shows that silica nanoparticle-polymer-flood has the highest oil recovery compared to water flood and conventional polymer flood [186].

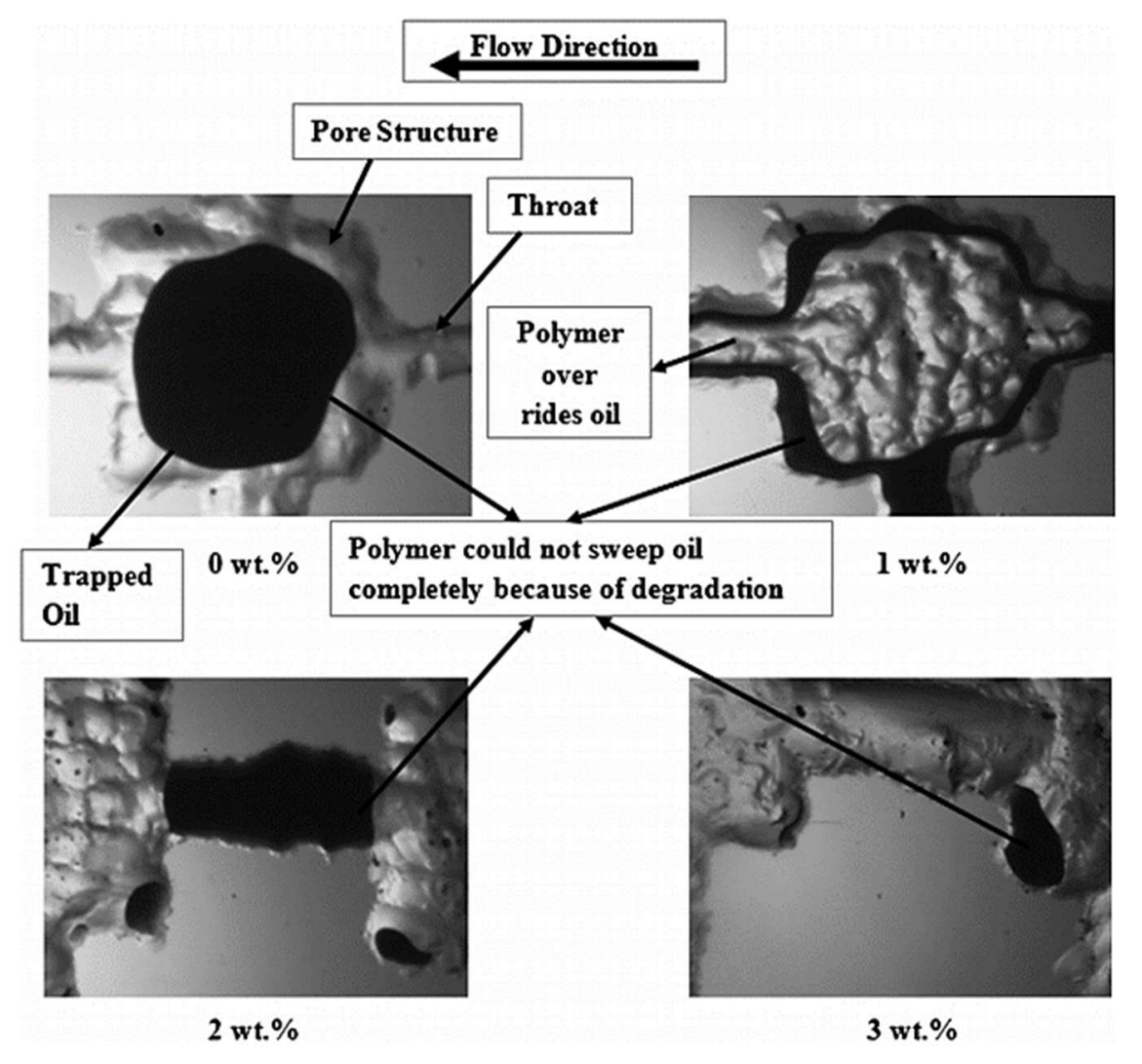

Figure 6. Glass micromodel picture of the oil displacement process with nano-polymer solution at different NP concentrations. Reproduced with permission from reference [83]. Copyright 2013 Taylor \& Francis.

Nanoclay has been shown to significantly increase the viscosity of the nanoclay-polymer solution and improve the stability of the mixture at a high temperature and salinity [187]. Cheraghian et al. [188] reported a 5-6\% higher recovery rate by adding nanoclay to a polymer solution. Several metal oxides such as $\mathrm{TiO}_{2}$ [91] and $\mathrm{FeO}$ [189] have also been shown to improve the sweep efficiency during EOR.

\section{Challenges and Future Research}

The future development of nano-EOR faces many challenges. The main challenges for the petroleum industry are the limitations of technology, economic aspects, and environmental and health issues. Even though numerous studies have shown that NPs could increase oil recovery, most of them are limited to small laboratory scales and are not yet applicable for large-scale field implementation. Several limitations hinder the application of NPs on a field scale:

- Stable nanofluids for larger-scale application are not difficult. As NPs tend to agglomerate under reservoir conditions (high temperature, pressure, and salinity), the preparation of homogenous NP suspensions is still a challenge.

- Several mechanisms for improving recovery in nano-EOR have been proposed. However, these mechanisms and the influencing parameters are not thoroughly understood. The interactions between NPs and rock surfaces need to be studied further.

- A fundamental understanding of nano-EOR is limited. The lack of theoretical and numerical investigation into nano-EOR seems to be one of the reasons for this. Most numerical studies refer 
to the colloidal particle model, which does not perfectly describe NP behavior. The models are also limited to the physical interactions of NPs and have not yet considered the chemical interactions.

- Due to the fast advancement of nanotechnology, health and safety studies are lagging behind. One of the important challenges for NP development is the lack of knowledge on the effects of various types of nanoparticles on the human body. Due to nano-scale size, NPs can be easily inhaled by humans and potentially deposited inside the lungs.

- In light of these challenges, future research on nano-EOR should focus on the following aspects:

- Research on the preparation of stable nanofluids in large quantities needs to be performed in consideration of economic aspects.

- Several NPs have proved to exhibit different characteristics and mechanisms for EOR. However, no research has yet been proposed on the application of mixtures of nanofluids. New applications and better performance may be possible by enabling two or more nanofluids to function together.

- Pilot projects of nano-EOR need to be carried out. These projects will improve the understanding of the nano-EOR processes in real-world conditions. Optimization studies on nano-EOR parameters are also recommended to improve recovery and cost efficiency.

- Experimental work needs to be done to confirm the adsorption and desorption behavior during NP flow. Reversible and irreversible adsorption need be studied further, both experimentally and theoretically, because they will affect the deliverability of NPs to the target zone.

- Integrated research on the health and safety of NPs must be done to prevent the risk to humans and the environment.

\section{Conclusions}

Numerous studies on the application of nanotechnology in the petroleum industry, especially for EOR, have been carried out and have shown promising results. Apart from the applications in exploration, drilling \& completion, stimulation \& production, and refinery, the application in EOR, namely Nano-EOR, has emerged as a promising alternative for the existing EOR technologies to improve the ultimate oil recovery. The most widely used nanomaterial for Nano-EOR is the NP, which has several advantages: (1) nanoscale particle size with a high surface area-to-volume ratio and high mobility through porous rock formation; (2) the potential to improve fluid performance with only a small amount; (3) improved heat and mass transfer with applicability in high-temperature conditions; and (4) high flexibility in combining with other materials such as surfactants and polymers. So far, various types of NPs (both organic and inorganic), as exemplified by the most common silica, are confirmed to be able to deliver additional oil recovery up to $20 \%$, through several well-documented mechanisms including IFT reduction, wettability alteration, disjoining pressure, and mobility ratio control. Different parameters, like NP concentration, size, temperature, wettability, and salinity, have been recognized to affect the performance of nanofluid flooding in nano-EOR. Despite the substantially increasing interests in Nano-EOR, no filed application has been reported and current study remains at the laboratory scale. Therefore, further research is required to fill the gap between laboratory tests and field-scale implementation.

Acknowledgments: The authors would like to thank the financial support from Department of Energy and Petroleum Engineering, University of Stavanger for this project.

Conflicts of Interest: The authors declare no conflict of interest.

\section{References}

1. Kong, X.; Ohadi, M. Applications of micro and nano technologies in the oil and gas industry-an overview of the recent progress. In Proceedings of the Abu Dhabi International Petroleum Exhibition and Conference, Abu Dhabi, UAE, 1-4 Nomverber 2010; Society of Petroleum Engineering: Richardson, TX, USA, 2010. 
2. Hendraningrat, L.; Torsæter, O. Metal oxide-based nanoparticles: Revealing their potential to enhance oil recovery in different wettability systems. Appl. Nanosci. 2015, 5, 181-199. [CrossRef]

3. Ju, B.; Fan, T. Enhanced oil recovery by flooding with hydrophilic nanoparticles. China Particuol. 2006, 4, 41-46. [CrossRef]

4. Li, S. An experimental Investigation of Enhanced Oil Recovery Mechanisms in Nanofluid Injection Process. PhD Thesis, Norwegian University of Science and Technology, Trondheim, Norway, 2016.

5. Fletcher, A.; Davis, J. How EOR can be transformed by nanotechnology. In Proceedings of the SPE Improved Oil Recovery Symposium, Tulsa, OK, USA, 24-28 April 2010; Society of Petroleum Engineering: Richardson, TX, USA, 2010.

6. Guo, K.; Li, H.; Yu, Z. In-situ heavy and extra-heavy oil recovery: A review. Fuel 2016, 185, 886-902. [CrossRef]

7. Zhang, T.; Roberts, M.; Bryant, S.L.; Huh, C. Foams and emulsions stabilized with nanoparticles for potential conformance control applications. In Proceedings of the SPE International Symposium on Oilfield Chemistry, The Woodlands, TX, USA, 20-22 April 2009; Society of Petroleum Engineers: Richardson, TX, USA, 2010.

8. Espinoza, D.A.; Caldelas, F.M.; Johnston, K.P.; Bryant, S.L.; Huh, C. Nanoparticle-stabilized supercritical $\mathrm{CO}_{2}$ foams for potential mobility control applications. In Proceedings of the SPE Improved Oil Recovery Symposium, Tulsa, OK, USA,, 24-28 April 2010; Society of Petroleum Engineers: Richardson, TX, USA, 2010.

9. Ju, B.; Dai, S.; Luan, Z.; Zhu, T.; Su, X.; Qiu, X. A study of wettability and permeability change caused by adsorption of nanometer structured polysilicon on the surface of porous media. In Proceedings of the SPE Asia Pacific Oil and Gas Conference and Exhibition, Melbourne, Australia, 8-10 October 2002; Society of Petroleum Engineers: Richardson, TX, USA, 2002.

10. Guo, K.; Li, H.; Yu, Z. Metallic nanoparticles for enhanced heavy oil recovery: Promises and challenges. Energy Procedia 2015, 75, 2068-2073. [CrossRef]

11. Hendraningrat, L.; Engeset, B.; Suwarno, S.; Torsæter, O. Improved oil recovery by nanofluids flooding: An experimental study. In Proceedings of the SPE Kuwait International Petroleum Conference and Exhibition, Kuwait City, Kuwait, 10-12 December 2012; Society of Petroleum Engineers: Richardson, TX, USA, 2012.

12. Onyekonwu, M.O.; Ogolo, N.A. Investigting the use of nanoparticles in enhancing oil recovery. In Proceedings of the Nigeria Annual International Conference and Exhibition, Tinapa-Calabar, Nigeria, 31 July-7 August 2010; Society of Petroleum Engineers: Richardson, TX, USA, 2010.

13. Sun, X.; Zhang, Y.; Chen, G.; Gai, Z. Application of nanoparticles in enhanced oil recovery: A critical review of recent progress. Energies 2017, 10, 345. [CrossRef]

14. Cheraghian, G.; Hendraningrat, L. A review on applications of nanotechnology in the enhanced oil recovery part A: Effects of nanoparticles on interfacial tension. Int. Nano Lett. 2016, 6, 129-138. [CrossRef]

15. Cheraghian, G.; Hendraningrat, L. A review on applications of nanotechnology in the enhanced oil recovery part B: Effects of nanoparticles on flooding. Int. Nano Lett. 2016, 6, 1-10. [CrossRef]

16. Guo, K.; Zhang, Y.H.; Shi, Q.; Yu, Z.X. The effect of carbon-supported nickel nanoparticles in the reduction of carboxylic acids for in situ upgrading of heavy crude oil. Energy Fuels 2017, 31, 6045-6055. [CrossRef]

17. Guo, K.; Gu, M.F.; Yu, Z.X. Carbon nanocatalysts for aquathermolysis of heavy crude oil: Insights into thiophene hydrodesulfurization. Energy Technol. 2017, 5, 1228-1234. [CrossRef]

18. Guo, K.; Hansen, V.F.; Li, H.L.; Yu, Z.X. Monodispersed nickel and cobalt nanoparticles in desulfurization of thiophene for in-situ upgrading of heavy crude oil. Fuel 2018, 211, 697-703. [CrossRef]

19. Zhang, T. Modeling of Nanoparticle Transport in Porous Media. PhD Thesis, University of Texas Austin, Austin, TX, USA, 2012.

20. Song, Y.; Marcus, C. Hyperpolarized silicon nanoparticles: Reinventing oil exploration. Presented at the Schlumberger Seminar, Schlumberger, College Station, TX, USA, 29-31 January 2007.

21. Jahagirdar, S.R. Oil-microbe detection tool using nano optical fibers. In Proceedings of the SPE Western Regional and Pacific Section AAPG Joint Meeting, Bakersfield, CA, USA, 29 March-4 April 2008; Society of Petroleum Engineers: Richardson, TX, USA, 2008.

22. Pratyush, S.; Sumit, B. Nano-Robots System and Methods for Well Logging and Borehole Measurements. U.S. Patent 20100242585A1, 12 November 2010.

23. Li, J.; Meyyappan, M. Real Time Oil Reservoir Evaluation Using Nanotechnology. U.S. Patent 7875455B1, 25 January 2011. 
24. Al-Shehri, A.A.; Ellis, E.S.; Servin, J.M.F.; Kosynkin, D.V.; Kanj, M.Y.; Schmidt, H.K. Illuminating the reservoir: Magnetic nanomappers. In Proceedings of the SPE Middle East Oil and Gas Show and Conference, Manama, Bahrain, 10-13 March 2013; Society of Petroleum Engineers: Richardson, TX, USA, 2013.

25. Rahmani, A.R.; Bryant, S.; Huh, C.; Athey, A.E.; Ahmadian, M.; Chen, J.; Wilt, M. Crosswell magnetic sensing of superparamagnetic nanoparticles for subsurface applications. SPE J. 2015, 20, 1067-1082. [CrossRef]

26. Sharma, M.M.; Zhang, R.; Chenevert, M.E.; Ji, L.; Guo, Q.; Friedheim, J. A new family of nanoparticle based drilling fluids. In Proceedings of the SPE Annual Technical Conference and Exhibition, San Antonio, TX, USA, 8-10 October 2012; Society of Petroleum Engineers: Richardson, TX, USA, 2012.

27. Cai, J.; Chenevert, M.E.; Sharma, M.M.; Friedheim, J.E. Decreasing water invasion into atoka shale using nonmodified silica nanoparticles. SPE Drill. Complet. 2012, 27, 103-112. [CrossRef]

28. Chakraborty, S.; Agrawal, G.; DiGiovanni, A.; Scott, D.E. The trick is the surface-Functionalized nanodiamond PDC technology. In Proceedings of the SPE International Oilfield Nanotechnology Conference and Exhibition, Noordwijk, The Netherlands, 12-14 June 2012; Society of Petroleum Engineers: Richardson, TX, USA, 2012.

29. Santra, A.K.; Boul, P.; Pang, X. Influence of nanomaterials in oilwell cement hydration and mechanical properties. In Proceedings of the SPE International Oilfield Nanotechnology Conference and Exhibition, Noordwijk, The Netherlands, 12-14 June 2012; Society of Petroleum Engineers: Richardson, TX, USA, 2012.

30. Gurluk, M.R.; Wang, G.; Nasr-El-Din, H.A.; Crews, J.B. The effect of different brine solutions on the viscosity of VES micelles. In Proceedings of the SPE European Formation Damage Conference \& Exhibition, Noordwijk, The Netherlands, 5-7 June 2013; Society of Petroleum Engineers: Richardson, TX, USA, 2013.

31. Murtaza, M.; Rahman, M.; Al-Majed, A. Mechanical and microstructural studies of nanoclay based oil well cement mix under high pressure and temperature application. In Proceedings of the International Petroleum Technology Conference, Bangkok, Thailand, 14-16 November 2016; International Petroleum Technology Conference: Richardson, TX, USA, 2016.

32. Khan, W.; Rahman, M.; Mahmoud, M.; Sarmah, P. MWCNT for enhancing mechanical properties of oil well cement for HPHT applications. In Proceedings of the SPE/IADC Middle East Drilling Technology Conference and Exhibition, Abu Dhabi, UAE, 26-28 January 2016; Society of Petroleum Engineers: Richardson, TX, USA, 2016.

33. Sun, X.; Wu, Q.; Zhang, J.; Qing, Y.; Wu, Y.; Lee, S. Rheology, Curing temperature and mechanical performance of oil well cement: Combined effect of cellulose nanofibers and graphene nano-platelets. Mater. Des. 2017, 114, 92-101. [CrossRef]

34. Crews, J.B.; Huang, T.; Wood, W.R. The future of fracturing-fluid technology and rates of hydrocarbon recovery. In Proceedings of the SPE Annual Technical Conference and Exhibition, Denver, CO, USA, 21-24 September 2008; Society of Petroleum Engineers: Richardson, TX, USA, 2008.

35. Bhatia, K.H.; Chacko, L.P. Ni-Fe nanoparticle: An innovative approach for recovery of hydrates. In Proceedings of the Brasil Offshore, Macaé, Brazil, 14-17 June 2011; Society of Petroleum Engineers: Richardson, TX, USA, 2011.

36. Crews, J.B.; Gomaa, A.M. Nanoparticle associated surfactant micellar fluids: An alternative to crosslinked polymer systems. In Proceedings of the SPE International Oilfield Nanotechnology Conference and Exhibition, Noordwijk, The Netherlands, 12-14 June 2012; Society of Petroleum Engineers: Richardson, TX, USA, 2012.

37. Li, L.; Al-Muntasheri, G.A.; Liang, F. Nanomaterials-enhanced high-temperature fracturing fluids prepared with untreated seawater. In Proceedings of the SPE Annual Technical Conference and Exhibition, Dubai, UAE, 26-28 September 2016; Society of Petroleum Engineers: Richardson, TX, USA, 2016.

38. Suleimanov, B.; Ismailov, F.; Veliyev, E. Nanofluid for enhanced oil recovery. J. Petrol. Sci. Eng. 2011, 78, 431-437. [CrossRef]

39. Mohajeri, A.; Rashidi, A.; Jozani, K.J.; Khorami, P.; Amini, B.; Parviz, D.; Kalbasi, M. Hydrodesulphurization Nanocatalyst, Its Use and A Process for Its Production. U.S. Patent 20100167915A1, 22 January 2010.

40. Hansen, L.P.; Ramasse, Q.M.; Kisielowski, C.; Brorson, M.; Johnson, E.; Topsøe, H.; Helveg, S. Atomic-scale edge structures on industrial-style $\mathrm{MoS}_{2}$ nanocatalysts. Angew. Chem. Int. Ed. 2011, 50, 10153-10156. [CrossRef] [PubMed]

41. Sotto, A.; Boromand, A.; Balta, S.; Kim, J.; Van der Bruggen, B. Doping of polyethersulfone nanofiltration membranes: Antifouling effect observed at ultralow concentrations of $\mathrm{TiO}_{2}$ nanoparticles. J. Mater. Chem. 2011, 21, 10311-10320. [CrossRef] 
42. Mohammadi, M.; Akbari, M.; Fakhroueian, Z.; Bahramian, A.; Azin, R.; Arya, S. Inhibition of asphaltene precipitation by $\mathrm{TiO}_{2}, \mathrm{SiO}_{2}$, and $\mathrm{ZrO}_{2}$ nanofluids. Energy Fuels 2011, 25, 3150-3156. [CrossRef]

43. Ko, S.; Prigiobbe, V.; Huh, C.; Bryant, S.L.; Bennetzen, M.V.; Mogensen, K. Accelerated oil droplet separation from produced water using magnetic nanoparticles. In Proceedings of the SPE Annual Technical Conference and Exhibition, Amsterdam, The Netherlands, 27-29 October 2014; Society of Petroleum Engineers: Richardson, TX, USA, 2014.

44. Patiño, J.E.; Cortés, F.B. Nanocatalysts for Hydrocracking and Methods of Their Use. U.S. Patent 9339796B2, 17 May 2016.

45. Bera, A.; Belhaj, H. Application of nanotechnology by means of nanoparticles and nanodispersions in oil recovery-a comprehensive review. J. Nat. Gas Sci. Eng. 2016, 34, 1284-1309. [CrossRef]

46. Kapusta, S.D.; Balzano, L.; te Riele, P. Nanotechnology applications in oil and gas exploration and production. In Proceedings of the International Petroleum Technology Conference, Bangkok, Thailand, 15-17 November 2011; International Petroleum Technology Conference: Richardson, TX, USA, 2011.

47. Bennetzen, M.V.; Mogensen, K. Novel applications of nanoparticles for future enhanced oil recovery. In Proceedings of the International Petroleum Technology Conference, Kuala Lumpur, Malaysia, 10-12 December 2014; International Petroleum Technology Conference: Richardson, TX, USA, 2014.

48. Schröder, L.; Lowery, T.J.; Hilty, C.; Wemmer, D.E.; Pines, A. Molecular imaging using a targeted magnetic resonance hyperpolarized biosensor. Science 2006, 314, 446-449. [CrossRef] [PubMed]

49. Cassidy, M.; Chan, H.; Ross, B.; Bhattacharya, P.; Marcus, C.M. In vivo magnetic resonance imaging of hyperpolarized silicon particles. Nat. Nanotechnol. 2013, 8, 363-368. [CrossRef] [PubMed]

50. Liu, H.; Jin, X.; Ding, B. Application of nanotechnology in petroleum exploration and development. Petrol. Explor. Dev. 2016, 43, 1107-1115. [CrossRef]

51. Amanullah, M.; Al-Tahini, A. Nano-technology-its significance in smart fluid development for oil and gas field application. In Proceedings of the SPE Saudi Arabia Section Technical Symposium, Al-Khobar, Saudi Arabia, 9-11 May 2009; Society of Petroleum Engineers: Richardson, TX, USA, 2009.

52. Apaleke, A.S.; Al-Majed, A.A.; Hossain, M.E. Drilling fluid: State of the art and future trend. In Proceedings of the North Africa Technical Conference and Exhibition, Cairo, Egypt, 20-22 February 2012; Society of Petroleum Engineers: Richardson, TX, USA, 2012.

53. Amanullah, M.; AlArfaj, M.K.; Al-abdullatif, Z.A. Preliminary test results of nano-based drilling fluids for oil and gas field application. In Proceedings of the SPE/IADC Drilling Conference and Exhibition, Amsterdam, The Netherlands, 1-3 March 2011; Society of Petroleum Engineers: Richardson, TX, USA, 2011.

54. Hoelscher, K.P.; De Stefano, G.; Riley, M.; Young, S. Application of nanotechnology in drilling fluids. In Proceedings of the SPE international oilfield nanotechnology conference and exhibition, Noordwijk, The Netherlands, 12-14 June 2012; Society of Petroleum Engineers: Richardson, TX, USA, 2012.

55. Srivatsa, J.T.; Ziaja, M.B. An experimental investigation on use of nanoparticles as fluid loss additives in a surfactant-polymer based drilling fluids. In Proceedings of the International Petroleum Technology Conference, Bangkok, Thailand, 15-17 November 2011.

56. Aderibigbe, A.A.; Cheng, K.; Heidari, Z.; Killough, J.E.; Fuss, T.; Stephens, W. Detection of propping agents in fractures using magnetic susceptibility measurements enhanced by magnetic nanoparticles. In Proceedings of the SPE Annual Technical Conference and Exhibition, Amsterdam, The Netherlands, 27-29 October 2014; Society of Petroleum Engineers: Richardson, TX, USA, 2014.

57. Contreras, O.; Hareland, G.; Husein, M.; Nygaard, R.; Al-Saba, M. Application of in-house prepared nanoparticles as filtration control additive to reduce formation damage. In Proceedings of the SPE International Symposium and Exhibition on Formation Damage Control, Lafayette, LA, USA, 26-28 February 2014; Society of Petroleum Engineers: Richardson, TX, USA, 2014.

58. Ho, C.Y.; Yusup, S.; Soon, C.V.; Arpin, M.T. Rheological behaviour of graphene nano-sheets in hydrogenated oil-based drilling fluid. Procedia Eng. 2016, 148, 49-56. [CrossRef]

59. Quercia, G.; Brouwers, H.; Garnier, A.; Luke, K. Influence of olivine nano-silica on hydration and performance of oil-well cement slurries. Mater. Des. 2016, 96, 162-170. [CrossRef]

60. Jafariesfad, N.; Gong, Y.; Geiker, M.R.; Skalle, P. Nano-sized mgo with engineered expansive property for oil well cement systems. In Proceedings of the SPE Bergen One Day Seminar, Grieghallen, Bergen, Norway, 20 April 2016; Society of Petroleum Engineers: Richardson, TX, USA, 2016. 
61. De la Roij, R.; Egyed, C.; Lips, J.-P. Nano-engineered oil well cement improves flexibility and increases compressive strength: A laboratory study. In Proceedings of the SPE International Oilfield Nanotechnology Conference and Exhibition, Noordwijk, The Netherlands, 12-14 June 2012; Society of Petroleum Engineers: Richardson, TX, USA, 2012.

62. Sengupta, S.; Kumar, A. Nano-ceramic coatings-a means of enhancing bit life and reducing drill string trips. In Proceedings of the IPTC, Beijing, China, 26-28 March 2013; International Petroleum Technology Conference: Richardson, TX, USA, 2013.

63. Mueller, H.; Herold, C.-P.; Bongardt, F.; Herzog, N.; von Tapavicza, S. Lubricants for Drilling Fluids. U.S. Patent 6806235B1, 19 October 2004.

64. Moh'd Husein, M.; Hareland, G. Drilling Fluids with Nano and Granular Particles and Their Use for Wellbore Strengthening. U.S. Patent 20150126415A1, 20 March 2018.

65. Roddy, C.W.; Covington, R.L. Cement Compositions and Methods Utilizing Nano-Clay. U.S. Patent 9512346B2, 6 December 2016.

66. Roddy, C.W. Cement Compositions and Methods Utilizing Nano-Hydraulic Cement. U.S. Patent 8603952B2, 10 December 2013.

67. Kuhn, K.-D. Bone Cement Mixture and X-ray Contrast Medium as Well as Method for Their Preparation. U.S. Patent 20040029996A1, 15 August 2006.

68. Wu, J.; Lei, Q.; Xiong, C.; Cao, G.; Zhang, J.; Li, J.; Fang, J.; Tan, J.; Ai, T.; Li, N.; et al. A nano-particle foam unloading agent applied in unloading liquid of deep gas well. Pet. Explor. Dev. 2016, 43, 695-700. [CrossRef]

69. Sun, Z.; Jing, G.; Tu, Z. Effect of modified nano-silica/EVA on flow behavior and wax crystallization of model oils with different wax content. J. Dispers. Sci. Technol. 2018, 39, 71-76. [CrossRef]

70. Davidson, A.; Huh, C.; Bryant, S.L. Focused magnetic heating utilizing superparamagnetic nanoparticles for improved oil production applications. In Proceedings of the SPE International Oilfield Nanotechnology Conference and Exhibition, Noordwijk, The Netherlands, 12-14 June 2012; Society of Petroleum Engineers: Richardson, TX, USA, 2012.

71. Gavrielatos, E.; Mohan, R.; Shoham, O. Effect of intermediate wettability nanoparticles on oil-water emulsion stability. J. Petrol. Sci. Eng. 2017, 152, 664-674. [CrossRef]

72. Singh, R.; Panthi, K.; Mohanty, K.K. Microencapsulation of acids by nanoparticles for acid treatment of shales. Energy Fuels 2017, 31, 11755-11764. [CrossRef]

73. Huang, T.; Crews, J.B. Nanotechnology applications in viscoelastic surfactant stimulation fluids. SPE Prod. Oper. 2008, 23, 512-517. [CrossRef]

74. Barati, R.; Johnson, S.J.; McCool, S.; Green, D.W.; Willhite, G.P.; Liang, J.T. Fracturing fluid cleanup by controlled release of enzymes from polyelectrolyte complex nanoparticles. J. Appl. Polym. Sci. 2011, 121, 1292-1298. [CrossRef]

75. Ghahfarokhi, R.B. Nano-Proppants for Fracture Conductivity. U.S. Patent 20160355727A1, 8 December 2016.

76. Al-Muntasheri, G.; Liang, F.; Ow, H.; Cox, J.; Poitzsch, M.E. High Temperature Fracturing Fluids with Nano-Crosslinkers. U.S. Patent 9862878B2, 9 January 2018.

77. Ying, J.Y.; Sun, T. Research needs assessment on nanostructured catalysts. J. Electroceram. 1997, 1, $219-238$. [CrossRef]

78. Kisielowski, C.; Ramasse, Q.M.; Hansen, L.P.; Brorson, M.; Carlsson, A.; Molenbroek, A.M.; Topsøe, H.; Helveg, S. Imaging $\mathrm{MoS}_{2}$ nanocatalysts with single-atom sensitivity. Angew. Chem. Int. Ed. 2010, 49, 2708-2710. [CrossRef] [PubMed]

79. Miranda, C.R.; Lara, L.S.D.; Tonetto, B.C. Stability and mobility of functionalized silica nanoparticles for enhanced oil recovery applications. In Proceedings of the SPE International Oilfield Nanotechnology Conference and Exhibition, Noordwijk, The Netherlands, 12-14 June 2012; Society of Petroleum Engineers: Richardson, TX, USA, 2012.

80. Nazari Moghaddam, R.; Bahramian, A.; Fakhroueian, Z.; Karimi, A.; Arya, S. Comparative study of using nanoparticles for enhanced oil recovery: Wettability alteration of carbonate rocks. Energy Fuels 2015, 29, 2111-2119. [CrossRef]

81. Haroun, M.R.; Alhassan, S.; Ansari, A.A.; Al Kindy, N.A.M.; Abou Sayed, N.; Kareem, A.; Ali, B.; Sarma, H.K. Smart nano-eor process for abu dhabi carbonate reservoirs. In Proceedings of the Abu Dhabi International Petroleum Conference and Exhibition, Abu Dhabi, UAE, 11-14 November 2012; Society of Petroleum Engineers: Richardson, TX, USA, 2012. 
82. Shahrabadi, A.; Bagherzadeh, H.; Roostaie, A.; Golghanddashti, H. Experimental investigation of hlp nanofluid potential to enhance oil recovery: A mechanistic approach. In Proceedings of the SPE International Oilfield Nanotechnology Conference and Exhibition, Noordwijk, The Netherlands, 12-14 June 2012; Society of Petroleum Engineers: Richardson, TX, USA, 2012.

83. Maghzi, A.; Kharrat, R.; Mohebbi, A.; Ghazanfari, M.H. The impact of silica nanoparticles on the performance of polymer solution in presence of salts in polymer flooding for heavy oil recovery. Fuel 2014, 123, 123-132. [CrossRef]

84. Hendraningrat, L.; Li, S.; Torsaeter, O. Enhancing oil recovery of low-permeability berea sandstone through optimised nanofluids concentration. In Proceedings of the SPE Enhanced Oil Recovery Conference, Kuala Lumpur, Malaysia, 2-4 July 2013; Society of Petroleum Engineers: Richardson, TX, USA, 2013.

85. Ehtesabi, H.; Ahadian, M.M.; Taghikhani, V. Enhanced heavy oil recovery using $\mathrm{TiO}_{2}$ nanoparticles: Investigation of deposition during transport in core plug. Energy Fuels 2014, 29, 1-8. [CrossRef]

86. Joonaki, E.; Ghanaatian, S. The application of nanofluids for enhanced oil recovery: Effects on interfacial tension and coreflooding process. Petrol. Sci. Technol. 2014, 32, 2599-2607. [CrossRef]

87. Hendraningrat, L.; Torsaeter, O. Unlocking the potential of metal oxides nanoparticles to enhance the oil recovery. In Proceedings of the Offshore Technology Conference-Asia, Kuala Lumpur, Malaysia, 25-28 March 2014.

88. Sharma, T.; Kumar, G.S.; Sangwai, J.S. Comparative effectiveness of production performance of pickering emulsion stabilized by nanoparticle-surfactant-polymer over surfactant-polymer (sp) flooding for enhanced oil recoveryfor brownfield reservoir. J. Petrol. Sci. Eng. 2015, 129, 221-232. [CrossRef]

89. El-diasty, A.I.; Aly, A.M. Understanding the mechanism of nanoparticles applications in enhanced oil recovery. In Proceedings of the SPE North Africa Technical Conference and Exhibition, Cairo, Egypt, 14-16 September 2015; Society of Petroleum Engineers: Richardson, TX, USA, 2015.

90. Cheraghian, G. Effects of nanoparticles on wettability: A review on applications of nanotechnology in the enhanced oil recovery. Int. J. Nano Dimens. 2015, 6, 443-452.

91. Cheraghian, G. Effects of titanium dioxide nanoparticles on the efficiency of surfactant flooding of heavy oil in a glass micromodel. Petrol. Sci. Technol. 2016, 34, 260-267. [CrossRef]

92. Alnarabiji, M.S.; Yahya, N.; Shafie, A.; Solemani, H.; Chandran, K.; Hamid, S.B.A.; Azizi, K. The influence of hydrophobic multiwall carbon nanotubes concentration on enhanced oil recovery. Procedia Eng. 2016, 148, 1137-1140. [CrossRef]

93. Jafarnezhad, M.; Giri, M.S.; Alizadeh, M. Impact of $\mathrm{SnO}_{2}$ nanoparticles on enhanced oil recovery from carbonate media. Energy Source Part A 2017, 39, 121-128. [CrossRef]

94. Towler, B.F.; Lehr, H.L.; Austin, S.W.; Bowthorpe, B.; Feldman, J.H.; Forbis, S.K.; Germack, D.; Firouzi, M. Spontaneous imbibition experiments of enhanced oil recovery with surfactants and complex nano-fluids. J. Surfactants Deterg. 2017, 20,367-377. [CrossRef]

95. Zhang, T.; Davidson, D.; Bryant, S.L.; Huh, C. Nanoparticle-stabilized emulsions for applications in enhanced oil recovery. In Proceedings of the SPE Improved Oil Recovery Symposium, Tulsa, OK, USA, 24-28 April 2010; Society of Petroleum Engineers: Tulsa, OK, USA, 2010.

96. Binks, B.P.; Philip, J.; Rodrigues, J.A. Inversion of silica-stabilized emulsions induced by particle concentration. Langmuir 2005, 21, 3296-3302. [CrossRef] [PubMed]

97. Binks, B.P.; Rodrigues, J.A. Inversion of emulsions stabilized solely by ionizable nanoparticles. Angew. Chem. Int. Ed. 2005, 44, 441-444. [CrossRef] [PubMed]

98. Dickson, J.L.; Binks, B.P.; Johnston, K.P. Stabilization of carbon dioxide-in-water emulsions with silica nanoparticles. Langmuir 2004, 20, 7976-7983. [CrossRef] [PubMed]

99. Adkins, S.S.; Gohil, D.; Dickson, J.L.; Webber, S.E.; Johnston, K.P. Water-in-carbon dioxide emulsions stabilized with hydrophobic silica particles. Phys. Chem. Chem. Phys. 2007, 9, 6333-6343. [CrossRef] [PubMed]

100. Son, H.; Kim, H.; Lee, G.; Kim, J.; Sung, W. Enhanced oil recovery using nanoparticle-stabilized oil/water emulsions. Korean J. Chem. Eng. 2013, 31, 338-342. [CrossRef]

101. Maurya, N.K.; Mandal, A. Investigation of synergistic effect of nanoparticle and surfactant in macro emulsion based eor application in oil reservoirs. Chem. Eng. Res. Des. 2018, 132, 370-384. [CrossRef]

102. Sharma, T.; Suresh Kumar, G.; Sangwai, J.S. Enhanced oil recovery using oil-in-water $(o / w)$ emulsion stabilized by nanoparticle, surfactant and polymer in the presence of nacl. Geosyst. Eng. 2014, 17, 195-205. [CrossRef] 
103. Guo, F.; Aryana, S. An experimental investigation of nanoparticle-stabilized $\mathrm{CO}_{2}$ foam used in enhanced oil recovery. Fuel 2016, 186, 430-442. [CrossRef]

104. Yang, W.P.; Wang, T.F.; Fan, Z.X. Highly stable foam stabilized by alumina nanoparticles for eor: Effects of sodium cumenesulfonate and electrolyte concentrations. Energy Fuels 2017, 31, 9016-9025. [CrossRef]

105. Sun, Q.; Zhang, N.; Li, Z.M.; Wang, Y.H. Nanoparticle-stabilized foam for mobility control in enhanced oil recovery. Energy Technol. 2016, 4, 1084-1096. [CrossRef]

106. Yang, W.P.; Wang, T.F.; Fan, Z.X.; Miao, Q.; Deng, Z.Y.; Zhu, Y.Y. Foams stabilized by in situ-modified nanoparticles and anionic surfactants for enhanced oil recovery. Energy Fuels 2017, 31, 4721-4730. [CrossRef]

107. Yu, J.; Khalil, M.; Liu, N.; Lee, R. Effect of particle hydrophobicity on $\mathrm{CO}_{2}$ foam generation and foam flow behavior in porous media. Fuel 2014, 126, 104-108. [CrossRef]

108. Wang, P.; You, Q.; Han, L.; Deng, W.B.; Liu, Y.F.; Fang, J.C.; Gao, M.W.; Dai, C.L. Experimental study on the stabilization mechanisms of $\mathrm{CO}_{2}$ foams by hydrophilic silica nanoparticles. Energy Fuels 2018, 32, 3709-3715. [CrossRef]

109. Hendraningrat, L. Unlocking the Potential of Hydrophilic Nanoparticles as Novel Enhanced Oil Recovery Method: An Experimental Investigation. Ph.D. Thesis, Norwegian University of Science and Technology, Trondheim, Norway, 2015.

110. Metin, C.O.; Baran, J.R.; Nguyen, Q.P. Adsorption of surface functionalized silica nanoparticles onto mineral surfaces and decane/water interface. J. Nanopart. Res. 2012, 14, 1246. [CrossRef] [PubMed]

111. Wang, L.; Wang, Z.; Yang, H.; Yang, G. The study of thermal stability of the $\mathrm{SiO}_{2}$ powders with high specific surface area. Mater. Chem. Phys. 1999, 57, 260-263. [CrossRef]

112. Maghzi, A.; Mohebbi, A.; Kharrat, R.; Ghazanfari, M.H. Pore-scale monitoring of wettability alteration by silica nanoparticles during polymer flooding to heavy oil in a five-spot glass micromodel. Transp. Porous Media 2011, 87, 653-664. [CrossRef]

113. Sharma, T.; Sangwai, J.S. Silica nanofluids in polyacrylamide with and without surfactant: Viscosity, surface tension, and interfacial tension with liquid paraffin. J. Petrol. Sci. Eng. 2017, 152, 575-585. [CrossRef]

114. Sharma, T.; Iglauer, S.; Sangwai, J.S. Silica nanofluids in an oilfield polymer polyacrylamide: Interfacial properties, wettability alteration, and applications for chemical enhanced oil recovery. Ind. Eng. Chem. Res. 2016, 55, 12387-12397. [CrossRef]

115. Johnston, K.P.; da Rocha, S.R. Colloids in supercritical fluids over the last 20 years and future directions. J. Supercrit. Fluids 2009, 47, 523-530. [CrossRef]

116. Enick, R.M.; Olsen, D.K.; Ammer, J.R.; Schuller, W. Mobility and conformance control for $\mathrm{CO}_{2} \mathrm{EOR}$ via thickeners, foams, and gels-a literature review of 40 years of research and pilot tests. In Proceedings of the SPE Improved Oil Recovery Symposium, Tulsa, OK, USA, 14-18 April 2012; Society of Petroleum Engineers: Richardson, TX, USA, 2012.

117. AttarHamed, F.; Zoveidavianpoor, M.; Jalilavi, M. The incorporation of silica nanoparticle and alpha olefin sulphonate in aqueous $\mathrm{CO}_{2}$ foam: Investigation of foaming behavior and synergistic effect. Petrol. Sci. Technol. 2014, 32, 2549-2558. [CrossRef]

118. Kim, I.; Worthen, A.J.; Johnston, K.P.; DiCarlo, D.A.; Huh, C. Size-dependent properties of silica nanoparticles for pickering stabilization of emulsions and foams. J. Nanopart. Res. 2016, 18, 1-12. [CrossRef]

119. Hafshejani, L.D.; Tangsir, S.; Koponen, H.; Riikonen, J.; Karhunen, T.; Tapper, U.; Lehto, V.-P.; Moazed, H.; Naseri, A.A.; Hooshmand, A. Synthesis and characterization of $\mathrm{Al}_{2} \mathrm{O}_{3}$ nanoparticles by flame spray pyrolysis (FSP)-role of fe ions in the precursor. Powder Technol. 2016, 298, 42-49. [CrossRef]

120. Chang, H.; Chang, Y.C. Fabrication of $\mathrm{Al}_{2} \mathrm{O}_{3}$ nanofluid by a plasma arc nanoparticles synthesis system. J. Mater. Process. Technol. 2008, 207, 193-199. [CrossRef]

121. Tsuzuki, T.; McCormick, P.G. Mechanochemical synthesis of nanoparticles. J. Mater. Sci. 2004, 39, 5143-5146. [CrossRef]

122. Ogolo, N.; Olafuyi, O.; Onyekonwu, M. Enhanced oil recovery using nanoparticles. In Proceedings of the SPE Saudi Arabia Section Technical Symposium and Exhibition, Al-Khobar, Al-Khobar, Saudi Arabia, 8-11 April 2012; Society of Petroleum Engineers: Richardson, TX, USA, 2012.

123. Giraldo, J.; Benjumea, P.; Lopera, S.; Cortés, F.B.; Ruiz, M.A. Wettability alteration of sandstone cores by alumina-based nanofluids. Energy Fuels 2013, 27, 3659-3665. [CrossRef]

124. Zaid, H.M.; Yahya, N.; Latiff, N.R.A. The effect of nanoparticles crystallite size on the recovery efficiency in dielectric nanofluid flooding. J. Nano Res. 2013, 21, 103-108. [CrossRef] 
125. Alomair, O.A.; Matar, K.M.; Alsaeed, Y.H. Experimental study of enhanced-heavy-oil recovery in berea sandstone cores by use of nanofluids applications. SPE Reserv. Eval. Eng. 2015, 18, 387-399. [CrossRef]

126. Negin, C.; Ali, S.; Xie, Q. Application of nanotechnology for enhancing oil recovery-A review. Petroleum 2016, 2, 324-333. [CrossRef]

127. Shekhawat, D.S.; Aggarwal, A.; Agarwal, S.; Imtiaz, M. Magnetic recovery-injecting newly designed magnetic fracturing fluid with applied magnetic field for EOR. In Proceedings of the SPE Asia Pacific Hydraulic Fracturing Conference, Beijing, China, 24-26 August 2016; Society of Petroleum Engineers: Richardson, TX, USA, 2016.

128. Nassar, N.N.; Al-Jabari, M.E.; Husein, M.M. Removal of asphaltenes from heavy oil by nickel nano and micro particle adsorbents. In Proceedings of the IASTED International Conference, Crete, Greece, 29 September-1 October 2008; ACTA Press: Calgary, AB, Canada, 2008.

129. Nwidee, L.; Al-Anssari, S.; Barifcani, A.; Sarmadivaleh, M.; Iglauer, S. Nanofluids for enhanced oil recovery processes: Wettability alteration using zirconium oxide. In Proceedings of the Offshore Technology Conference Asia, Kuala Lumpur, Malaysia, 22-25 March 2016; Society of Petroleum Engineers: Richardson, TX, USA, 2016.

130. Ehtesabi, H.; Ahadian, M.M.; Taghikhani, V.; Ghazanfari, M.H. Enhanced heavy oil recovery in sandstone cores using $\mathrm{TiO}_{2}$ nanofluids. Energy Fuels 2013, 28, 423-430. [CrossRef]

131. Cheraghian, G. Effect of nano titanium dioxide on heavy oil recovery during polymer flooding. Petrol. Sci. Technol. 2016, 34, 633-641. [CrossRef]

132. Sedaghat, M.; Mohammadi, H.; Razmi, R. Application of $\mathrm{SiO}_{2}$ and $\mathrm{TiO}_{2}$ nano particles to enhance the efficiency of polymer-surfactant floods. Energ. Sources Part A 2016, 38, 22-28. [CrossRef]

133. Tajmiri, M.; Mousavi, S.M.; Ehsani, M.R.; Roayaei, E.; Emadi, A. Wettability alteration of sandstone and carbonate rocks by using zno nanoparticles in heavy oil reservoirs. Iran. J. Oil Gas Sci. Technol. 2016, 4, 50-66.

134. Latiff, N.R.A.; Yahya, N.; Zaid, H.M.; Demiral, B. Novel enhanced oil recovery method using dielectric zinc oxide nanoparticles activated by electromagnetic waves. In Proceedings of the National Postgraduate Conference (NPC), Kuala Lumpur, Malaysia, 19-20 September 2011.

135. Adil, M.; Zaid, H.M.; Chuan, L.K.; Latiff, N.R.A. Effect of dispersion stability on electrorheology of water-based zno nanofluids. Energy Fuels 2016, 30, 6169-6177. [CrossRef]

136. Karimi, A.; Fakhroueian, Z.; Bahramian, A.; Pour Khiabani, N.; Darabad, J.B.; Azin, R.; Arya, S. Wettability alteration in carbonates using zirconium oxide nanofluids: EOR implications. Energy Fuels 2012, 26, 1028-1036. [CrossRef]

137. Moslan, M.S.; Sulaiman, W.; Rosli, W.; Ismail, A.R.; Jaafar, M.Z.; Ismail, I. Wettability alteration of dolomite rock using nanofluids for enhanced oil recovery. Mater. Sci. Forum 2016, 864, 194-198. [CrossRef]

138. Esmaeilzadeh, P.; Hosseinpour, N.; Bahramian, A.; Fakhroueian, Z.; Arya, S. Effect of $\mathrm{ZrO}_{2}$ nanoparticles on the interfacial behavior of surfactant solutions at air-water and n-heptane-water interfaces. Fluid Phase Equilib. 2014, 361, 289-295. [CrossRef]

139. Fakirov, S.; Bhattacharyya, D.; Panamoottil, S.M. Converting of bulk polymers into nanosized materials with controlled nanomorphology. Int. J. Polym. Mater. Polym. Biomater. 2014, 63, 777-793. [CrossRef]

140. Rao, J.P.; Geckeler, K.E. Polymer nanoparticles: Preparation techniques and size-control parameters. Prog. Polym. Sci. 2011, 36, 887-913. [CrossRef]

141. ShamsiJazeyi, H.; Miller, C.A.; Wong, M.S.; Tour, J.M.; Verduzco, R. Polymer-coated nanoparticles for enhanced oil recovery. J. Appl. Polym. Sci. 2014, 131. [CrossRef]

142. Wang, L.; Zhang, G.; Li, G.; Zhang, J.; Ding, B. Preparation of microgel nanospheres and their application in EOR. In Proceedings of the International Oil and Gas Conference and Exhibition in China, Beijing, China, 8-10 June 2010; Society of Petroleum Engineers: Richardson, TX, USA, 2010.

143. Horikoshi, S.; Serpone, N. Introduction to nanoparticles. In Microwaves in Nanoparticle Synthesis: Fundamentals and Applications; Horikoshi, S., Serpone, N., Eds.; Wiley-VCH: Weinheim, Germany, 2013.

144. Shen, M.; Resasco, D.E. Emulsions stabilized by carbon nanotube-Silica nanohybrids. Langmuir 2009, 25, 10843-10851. [CrossRef] [PubMed]

145. Villamizar, L.C.; Lohateeraparp, P.; Harwell, J.H.; Resasco, D.E.; Shiau, B.J.B. Interfacially active swnt/silica nanohybrid used in enhanced oil recovery. In Proceedings of the SPE Improved Oil Recovery Symposium, Tulsa, OK, USA, 24-28 April 2010; Society of Petroleum Engineers: Richardson, TX, USA, 2010. 
146. Kadhum, M.J.; Swatske, D.P.; Chen, C.; Resasco, D.E.; Harwell, J.H.; Shiau, B. Propagation of carbon nanotube hybrids through porous media for advancing oilfield technology. In Proceedings of the SPE International Symposium on Oilfield Chemistry, The Woodlands, TX, USA, 13-15 April 2015; Society of Petroleum Engineers: Richardson, TX, USA, 2015.

147. AfzaliTabar, M.; Alaei, M.; Khojasteh, R.R.; Motiee, F.; Rashidi, A. Preference of multi-walled carbon nanotube (MWCNT) to single-walled carbon nanotube (SWCNT) and activated carbon for preparing silica nanohybrid pickering emulsion for chemical enhanced oil recovery (C-EOR). J. Solid State Chem. 2017, 245, 164-173. [CrossRef]

148. Kondiparty, K.; Nikolov, A.; Wu, S.; Wasan, D. Wetting and spreading of nanofluids on solid surfaces driven by the structural disjoining pressure: Statics analysis and experiments. Langmuir 2011, 27, 3324-3335. [CrossRef] [PubMed]

149. Mcelfresh, P.; Holcomb, D.; Ector, D. Application of nanofluid technology to improve recovery in oil and gas. In Proceedings of the SPE International Oilfield Nanotechnology Conference and Exhibition, Noordwijk, The Netherlands, 12-14 June 2012; Society of Petroleum Engineers: Richardson, TX, USA, 2012.

150. Hendraningrat, L.; Li, S.; Torsæter, O. Effect of some parameters influencing enhanced oil recovery process using silica nanoparticles: An experimental investigation. In Proceedings of the SPE Reservoir Characterization and Simulation Conference and Exhibition, Abu Dhabi, UAE, 16-18 September 2013; Society of Petroleum Engineers: Richardson, TX, USA, 2013.

151. Chengara, A.; Nikolov, A.D.; Wasan, D.T.; Trokhymchuk, A.; Henderson, D. Spreading of nanofluids driven by the structural disjoining pressure gradient. J. Colloid Interface Sci. 2004, 280, 192-201. [CrossRef] [PubMed]

152. Hendraningrat, L.; Li, S.; Torsæter, O. A coreflood investigation of nanofluid enhanced oil recovery. J. Petrol. Sci. Eng. 2013, 111, 128-138. [CrossRef]

153. Somasundaran, P.; Agar, G. The zero point of charge of calcite. J. Colloid Interface Sci. 1967, 24, 433-440. [CrossRef]

154. Worthen, A.J.; Tran, V.; Cornell, K.A.; Truskett, T.M.; Johnston, K.P. Steric stabilization of nanoparticles with grafted low molecular weight ligands in highly concentrated brines including divalent ions. Soft Matter 2016, 12, 2025-2039. [CrossRef] [PubMed]

155. Zhang, T.; Murphy, M.J.; Yu, H.; Bagaria, H.G.; Yoon, K.Y.; Nielson, B.M.; Bielawski, C.W.; Johnston, K.P.; Huh, C.; Bryant, S.L. Investigation of nanoparticle adsorption during transport in porous media. SPE J. 2014, 20, 667-677. [CrossRef]

156. Kanj, M.Y.; Funk, J.J.; Al-Yousif, Z. Nanofluid coreflood experiments in the ARAB-D. In Proceedings of the SPE Saudi Arabia Section Technical Symposium, Al-Khobar, Saudi Arabia, 9-11 May 2009; Society of Petroleum Engineers: Richardson, TX, USA, 2009.

157. Caldelas, F.M.; Murphy, M.; Huh, C.; Bryant, S.L. Factors governing distance of nanoparticle propagation in porous media. In Proceedings of the SPE Production and Operations Symposium, Oklahoma City, OK, USA, 27-29 March 2011; Society of Petroleum Engineers: Richardson, TX, USA, 2011.

158. Owens, W.; Archer, D. The effect of rock wettability on oil-water relative permeability relationships. J. Petrol. Technol. 1971, 23, 873-878. [CrossRef]

159. Morrow, N.R. Wettability and its effect on oil recovery. J. Petrol. Technol. 1990, 42, 476-484. [CrossRef]

160. Lorenz, P.B.; Donaldson, E.C.; Thomas, R.D. Use of Centrifugal Measurements of Wettability to Predict Oil Recovery; US Department of the Interior, Report of Investigations; US Department of the Interior: Washington, DC, USA, 1974.

161. Morrow, N.R. A review of the effects of initial saturation, pore structure and wettability on oil recovery by waterflooding. In Proceedings of the North Sea Oil and Gas Reservoirs, Trondheim, Norway, 2-4 December 1985; Graham and Trotman, Ltd.: London, UK, 1987.

162. Khilar, K.C.; Fogler, H.S. Migrations of Fines in Porous Media; Fogler, H.S., Ed.; Springer Science \& Business Media: Berlin, Germany, 1998; p. 12.

163. Wang, Y.; Xu, H.; Yu, W.; Bai, B.; Song, X.; Zhang, J. Surfactant induced reservoir wettability alteration: Recent theoretical and experimental advances in enhanced oil recovery. Petrol. Sci. 2011, 8, 463-476. [CrossRef]

164. Maerker, J.; Gale, W. Surfactant flood process design for loudon. SPE Reserv. Eng. 1992, 7, 36-44. [CrossRef] 
165. Hammond, P.S.; Unsal, E. Spontaneous imbibition of surfactant solution into an oil-wet capillary: Wettability restoration by surfactant-contaminant complexation. Langmuir 2011, 27, 4412-4429. [CrossRef] [PubMed]

166. Al-Anssari, S.; Barifcani, A.; Wang, S.; Iglauer, S. Wettability alteration of oil-wet carbonate by silica nanofluid. J. Colloid Interface Sci. 2016, 461, 435-442. [CrossRef] [PubMed]

167. Hendraningrat, L.; Torsaeter, O. Understanding fluid-fluid and fluid-rock interactions in the presence of hydrophilic nanoparticles at various conditions. In Proceedings of the SPE Asia Pacific Oil \& Gas Conference and Exhibition, Adelaide, Australia, 14-16 October 2014; Society of Petroleum Engineers: Richardson, TX, USA, 2014.

168. Roustaei, A.; Bagherzadeh, H. Experimental investigation of $\mathrm{SiO}_{2}$ nanoparticles on enhanced oil recovery of carbonate reservoirs. J. Petrol. Explor. Prod. Technol. 2015, 5, 27-33. [CrossRef]

169. Chatzis, I.; Morrow, N.R. Correlation of capillary number relationships for sandstone. SPE J. 1984, 24, 555-562. [CrossRef]

170. Melrose, J. Role of capillary forces in detennining microscopic displacement efficiency for oil recovery by waterflooding. J. Can. Petrol. Technol. 1974, 13. [CrossRef]

171. Munshi, A.; Singh, V.; Kumar, M.; Singh, J. Effect of nanoparticle size on sessile droplet contact angle. J. Appl. Phys. 2008, 103, 084315. [CrossRef]

172. Roustaei, A.; Moghadasi, J.; Bagherzadeh, H.; Shahrabadi, A. An experimental investigation of polysilicon nanoparticles' recovery efficiencies through changes in interfacial tension and wettability alteration. In Proceedings of the SPE International Oilfield Nanotechnology Conference and Exhibition, Noordwijk, The Netherlands, 12-14 June 2012; Society of Petroleum Engineers: Richardson, TX, USA, 2012.

173. Moghadam, T.F.; Azizian, S. Effect of $\mathrm{ZnO}$ nanoparticles on the interfacial behavior of anionic surfactant at liquid/liquid interfaces. Colloids Surf. A 2014, 457, 333-339. [CrossRef]

174. Bergeron, V. Forces and structure in thin liquid soap films. J. Phys. Condens. Matter 1999, 11, R215. [CrossRef]

175. Derjaguin, B.; Churaev, N. Structural component of disjoining pressure. J. Colloid Interface Sci. 1974, 49, $249-255$. [CrossRef]

176. Basu, S.; Sharma, M.M. Measurement of critical disjoining pressure for dewetting of solid surfaces. J. Colloid Interface Sci. 1996, 181, 443-455. [CrossRef]

177. Wasan, D.T.; Nikolov, A.D. Spreading of nanofluids on solids. Nature 2003, 423, 156-159. [CrossRef] [PubMed]

178. Wasan, D.; Nikolov, A.; Kondiparty, K. The wetting and spreading of nanofluids on solids: Role of the structural disjoining pressure. Curr. Opin. Colloid Interface Sci. 2011, 16, 344-349. [CrossRef]

179. Piech, M.; Walz, J.Y. Direct measurement of depletion and structural forces in polydisperse, charged systems. J. Colloid. Interface Sci. 2002, 253, 117-129. [CrossRef] [PubMed]

180. Wang, J.; Dong, M. Optimum effective viscosity of polymer solution for improving heavy oil recovery. J. Petrol. Sci. Eng. 2009, 67, 155-158. [CrossRef]

181. Sheng, J. Modern Chemical Enhanced Oil Recovery: Theory and Practice; Sheng, J., Ed.; Gulf Professional Publishing: Houston, TX, USA, 2010.

182. Ramsden, D.; McKay, K. Degradation of polyacrylamide in aqueous solution induced by chemically generated hydroxyl radicals: Part i-Fenton's reagent. Polym. Degrad. Stab. 1986, 14, 217-229. [CrossRef]

183. Ramsden, D.; McKay, K. The degradation of polyacrylamide in aqueous solution induced by chemically generated hydroxyl radicals: Part ii-autoxidation of $\mathrm{Fe}^{2+}$. Polym. Degrad. Stab. 1986, 15, 15-31. [CrossRef]

184. Zeyghami, M.; Kharrat, R.; Ghazanfari, M. Investigation of the applicability of nano silica particles as a thickening additive for polymer solutions applied in eor processes. Energy Sources Part A 2014, 36, 1315-1324. [CrossRef]

185. Cheraghian, G.; Hemmati, M.; Bazgir, S.; Singh, M.R. Application of $\mathrm{TiO}_{2}$ and fumed silica nanoparticles and improve the performance of drilling fluids. AIP Conf. Proc. 2014, 1590, 266-270.

186. Yousefvand, H.; Jafari, A. Enhanced oil recovery using polymer/nanosilica. Procedia Mater. Sci. 2015, 11, 565-570. [CrossRef]

187. Cheraghian, G.; Khalilinezhad, S. Effect of nanoclay on heavy oil recovery during polymer flooding. Petrol. Sci. Technol. 2015, 33, 999-1007. [CrossRef] 
188. Cheraghian, G. Thermal resistance and application of nanoclay on polymer flooding in heavy oil recovery. Petrol. Sci. Technol. 2015, 33, 1580-1586. [CrossRef]

189. Tarek, M.; El-Banbi, A.H. Comprehensive investigation of effects of nano-fluid mixtures to enhance oil recovery. In Proceedings of the SPE North Africa Technical Conference and Exhibition, Cairo, Egypt, 14-16 September 2015; Society of Petroleum Engineers: Richardson, TX, USA, 2015. 